\title{
Positional, mobility and reference effects: \\ How does social class affect life satisfaction in Europe?
}

\author{
Caspar Kaiser, ${ }^{\mathrm{a}, \mathrm{b}}$, Nhat An Trinh ${ }^{\mathrm{a}}$
}

April 2019

\begin{abstract}
This is an outdated version. A current version, accepted for publication in the European Sociological Review, can be downloaded here.
\end{abstract}

\begin{abstract}
In this study, we analyse the effects of social class on life satisfaction and develop a theoretical framework that shows how social class affects life satisfaction through five pathways. Informed by this framework, we estimate the direct effects of class destination and class origin, the effect of own intergenerational class mobility as well as the effects of others' class position and mobility (socalled reference effects). To do so, we utilize European Social Survey (ESS) waves 1 to 5 (2002-2010). We obtain information on life satisfaction as well as destination and origin class for about 100,000 respondents in 32 European countries. Our mobility analyses are performed with diagonal reference models, which allow for the consistent estimation of mobility effects. We find: (1) Class destination consistently and strongly structures life satisfaction across Europe. (2) Own class mobility positively impacts life satisfaction, particularly in Eastern Europe. (3) Other's class mobility has a strong negative effect on life satisfaction. Especially the latter finding points to the hitherto neglected importance of reference effects when considering the impact of social class on life satisfaction.
\end{abstract}

Keywords: subjective well-being, social class, ESeC, diagonal reference models, social mobility, reference effects

\footnotetext{
We thank Joan Madia for invaluable input in the initial stages of the project and his help in preparing the data. Further, we thank Bastian Betthäuser, John Goldthorpe, Brian Nolan and Maarten Vendrik for their extensive and insightful comments on earlier drafts. We also thank participants of the DSPI Inequality Research Group, as well as workshops at Nuffield College and the International Conference for Happiness and Health (University of Siena) for their useful suggestions.

aDepartment of Social Policy and Intervention, University of Oxford

bCorresponding author: Nuffield College. 1 New Road, Oxford. United Kingdom. E-mail: caspar.kaiser@nuffield.ox.ac.uk
} 


\section{Introduction}

The strong association between social class and life outcomes has been recognised as an enduring feature of advanced market societies. Past research provides overwhelming evidence that the upper classes enjoy a clear advantage over those towards the bottom of the class distribution: On average, they are more economically successful (Goldthorpe \& McKnight, 2006), better educated (Bernardi \& Ballarino, 2016; Shavit \& Blossfeld, 1993), lead healthier and longer lives (White et al., 2007), and offer their children greater opportunities for a self-determined and fulfilling life (Bukodi \& Goldthorpe, 2019). Occupying a sufficiently high class position, by either being born into it or achieving intergenerational upward mobility, should therefore truly matter for individuals' lives as well as their own personal evaluation thereof.

So far, quantitative scholarship has had only limited interest in the effects of social class, including class mobility, on life satisfaction. We know of only few studies with such focus (e.g. Hadjar \& Samuel, 2015; Iveson \& Deary, 2017; Marshall \& Firth, 1999) and the existing literature appears to suffer from certain shortcomings, limiting its ability to shed light on the complex relationship: First, the literature does not yet give an encompassing theorisation of all the ways through which class position and class mobility might affect life satisfaction. With respect to the effect of class mobility Sorokin's "dissociative" (1959) and Newman's “falling from grace" (1999) hypotheses are notable exceptions, but little favourable empirical evidence has so far been accumulated. Second, studies struggle to correctly distinguish between the effects of class position and class mobility. The only two studies which accurately implement the distinction either use data on happiness rather than life satisfaction and are conducted outside the group of advanced market societies (Zhao et al. 2017) or fail to include proper controls (Marshall \& Firth 1999). Finally, we note that the direct effects of own class position and parental class position beyond the effect of class mobility have also not been thoroughly examined. 
Against this background, the aim of this study is to provide a comprehensive account of how social class affects life satisfaction in Europe by addressing the shortcomings mentioned above. Most importantly, the effect of social class on life satisfaction has been conceptualized narrowly, focusing only on the effect of own social class. However, when societies change their class structure, or become more mobile overall, these macro-level changes may have effects that go beyond the individual's own experience of social class. To allow for such macro-level impacts, we include socalled reference effects into our framework. Reference effects relate to outcomes of others and are of great concern in the economic literature on the effects of income on life satisfaction. However, they have not yet been given attention in this sociological literature. By introducing reference effects into our study, we thus make, as we believe, an important contribution in both theoretical and empirical terms.

Furthermore, we examine the effect of social class on life satisfaction separately for Western and Eastern Europe. In light of the different political and economic trajectories of these two country groups, social class may structure inequalities in these societies differently and consequently exert heterogeneous effects on life satisfaction. Indeed, past research found a higher class gradient in mortality rates (Bessudnov, McKee, \& Stuckler, 2012; Vågerö, 2010), greater willingness to accept economic inequality (Kelley \& Zagorski, 2004), and a greater dependence of political attitudes on the experience of intergenerational social mobility (Gugushvili, 2016) in Eastern than in Western Europe.

The following section presents our theoretical framework. We then give an overview of previous findings before elaborating on our data and empirical approach. Thereafter we present and discuss our results. The final section concludes. 


\section{Theoretical framework}

We understand life satisfaction as the subjective and cognitively driven global evaluation of a person's entire life (Pavot \& Diener, 2008). This conceptualization is opposed to a person's affective wellbeing, in which they merely assess immediate feelings of wellbeing (Diener, Suh, Lucas, \& Smith, 1999). Regarding social class, we take a Neo-Weberian conception as pioneered by Goldthorpe and others based on employment relations (Erikson, Goldthorpe, \& Portocarero, 1979). According to this conception, the service relationship and wage contract constitute either end of the class schema with the salariat at the top and the working class at the bottom. Their application depends on the level of skills required to do the job and ease of monitoring. Selfemployment is recognised as a third ideal type of employment relations (Rose, Harrison, \& Pevalin, 2009).

Social class may affect life satisfaction through five pathways. First, one's own class (henceforth, class destination) may have effects on life satisfaction. Second, the social class of one's parents (henceforth, class origin) could have effects of their own. Third, people potentially make comparisons between their class origin and their class destination. Consequently, this difference, i.e. an individual's experience of intergenerational class mobility, may also affect life satisfaction. Finally, people compare themselves to peers. Therefore, other's class position (henceforth, reference position) and other's class mobility (henceforth, reference mobility) may be further class-related determinants of life satisfaction. 
Figure 1. Summary of theoretical framework.

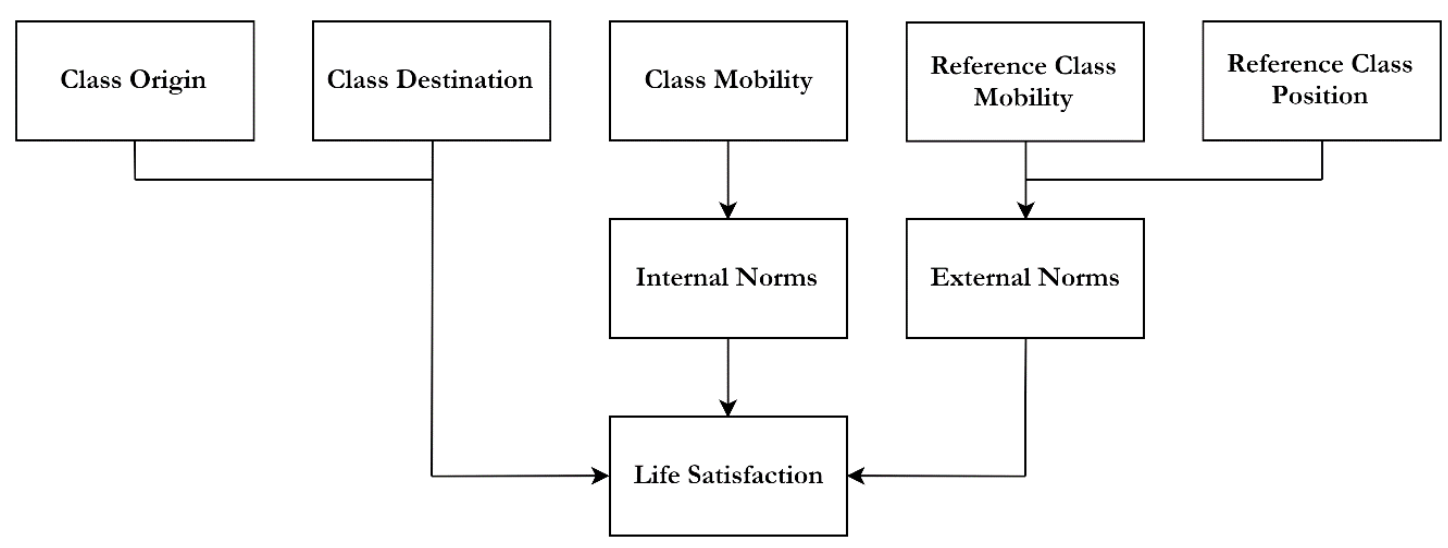

Income (e.g. Kahneman \& Deaton, 2010) and unemployment (e.g. Luechinger, Meier, \& Stutzer, 2010; Wulfgramm, 2014) are socio-economic outcomes that are known to be important in determining life satisfaction. Class destination determines socio-economic outcomes, and should thus also affect life satisfaction. Indeed, members of the working class, have lower current incomes and are exposed to greater income variability and economic instability than those in the salariat (Goldthorpe \& McKnight, 2006). Furthermore, the salaried classes experience income increases across the life course while those on wage contracts do not (Bihagen \& Nermo, 2010, Bukodi \& Goldthorpe 2019). Thus, class is related to poverty and material deprivation, a relation which persists beyond the effect of current income (Nolan \& Whelan, 2011). Finally, class predicts the occurrence and duration of under- and unemployment (Elias \& McKnight, 2003; Lucchini \& Schizzerotto, 2010; Warren, 2015).

Moreover, the salaried classes enjoy more autonomy, task discretion and variation, and greater power over others. They have more opportunities to develop new skills (Paugam \& Zhou, 2009) and are less exposed to health hazards (Melchior et al., 2005), each of which improves job satisfaction (Pichler \& Wallace, 2009). Jobs offering greater autonomy and power are also directly associated with life satisfaction (Drobnič, Beham, \& Präg, 2010). 
These considerations lead to our first hypothesis:

H1: Individuals whose class destination is better characterised by a service relationship (a higher social class) should report higher levels of life satisfaction than those whose social class is better described by a wage contract (a lower social class).

Individuals' parents have a strong tendency to transmit class-based inequalities to their children. Individuals with higher class origins are better equipped with inherited wealth, and economically opportune social networks, which reduce their risk of economic uncertainty and unemployment. Greater parental resources likewise allow children to obtain better education and thus more satisfying jobs (Shavit \& Blossfeld, 1993). Moreover, parents directly transmit health-related behaviours (Gugushvili et al., 2018). Direct effects of class origin on life satisfaction are thus possible. However, since socio-economic outcomes are more strongly predicted by class destination, we expect the effects of class origin on life satisfaction to be smaller. This yields our second hypothesis:

H2: Individuals with higher class origins should report greater life satisfaction than individuals with lower class origins, even when controlling for class destination. This effect should be smaller than the one postulated under H1.

That people compare themselves with their past is a well-known phenomenon. Individuals generate "internal norms" (Senik, 2009) and evaluate their situation as a function of the difference in quality of the present with the quality of the past (Frederick \& Loewenstein, 1999; Michalos, 1985). Internal norms have been most notably discussed with respect to income, where the difference between past incomes and present incomes may impact life satisfaction (Vendrik, 2013; Wolbring, Keuschnigg, \& Negele, 2013). If social class is similar in this respect, we should expect that, over and above the direct effects of class destination and class origin, there will be further effects emanating from the difference between class origin and class destination, i.e. from intergenerational 
class mobility. Newman's (1999) “falling from grace hypothesis" and Sorokin's (1959) “dissociative hypothesis" may be viewed as special cases of such effects of internal norms ${ }^{1}$. Newman's hypothesis states that downward mobility has negative effects, but is silent on upward mobility. Sorokin's hypothesis states that individuals feel more at ease in places of cultural familiarity. Thus, leaving one's origin class may lead to disorientation and stress implying that social mobility has negative effects regardless of the direction of mobility. Both hypotheses have featured widely in the previous literature on various outcomes, but could often not be corroborated (Houle, 2011; Houle \& Martin, 2011; Zang \& de Graaf, 2016; Zhao et al., 2017). Given the competing claims about upward class mobility (i.e. exceeding one’s internal norm vs. feeling “dissociated”), we have no prior expectation about the direction or presence of upward class mobility effects.

Hence our third hypothesis states:

H3: Downward intergenerational class mobility negatively impacts life satisfaction.

Furthermore, people compare themselves to others, and thus form "external norms". Here, life satisfaction is a function of the difference between the quality of one's own situation with that of one's peers, i.e. those in one's reference group. The presence of such external norms has been most notably discussed with respect to income (e.g. Delhey \& Kohler, 2006; Ferrer-i-Carbonell, 2005; McBride, 2001), and unemployment (Clark, 2003; Heggebø \& Elstad, 2018).

Concerning social class, individuals may compare their life that is structured by their own class with the lives of others in their reference group, which in turn is structured by their social class. If those in one's reference group predominantly occupy higher class destinations, one can be expected to evaluate one's live as worse. This is because such a more demanding external norm sets a higher bar for one's own achievement.

\footnotetext{
1 Often the literature (including us) treat Newman and Sorokin as concerned with intergenerational mobility, i.e. class differences between the parental and children generation. However, in reality both authors were concerned with intragenerational mobility, i.e. class changes during an individual's life course.
} 
This leads us to state:

H4a: Higher levels of reference class position negatively affect life satisfaction.

Analogously, if those within one's reference group have e.g. been predominantly more upwardly mobile and thus typically come from lower class origins, one may evaluate one's own performance more grimly: If I observe it to be the external norm that most of my peers come from lower class origins and thus have been upwardly mobile, I will consider my own class destination (and my ability to have been upwardly mobile) as relatively worse. I thus evaluate my life less favorably. Therefore, we expect:

H4b: Higher levels of upward reference class mobility negatively affects life satisfaction, while higher levels of downward reference class mobility positively affects life satisfaction.

The previous literature on reference income suggests that people mostly compare themselves with people who are similar to themselves, with work colleagues and friends being of particular importance (Clark \& Senik, 2010; Goerke \& Pannenberg, 2015). Those that either share one's own class destination or class origin, and those who are of similar age (following e.g. Ferrer-i-Carbonell, 2005; Vendrik \& Woltjer, 2007), likely resemble these sets of people. They may thus serve as a proxy for one's true reference group. Therefore, when considering reference class position, we take those coming from the same class origin to be members of the reference group. When instead considering reference class mobility, we include those achieving the same class destination ${ }^{2}$.

Hypotheses 1 to 4 pertain to both Eastern and Western Europe. However, there are important differences between these regions that lead us to believe that the strength of the associations between social class and life satisfaction differs. First, most Eastern European countries experienced large increases in income inequality (Grosfeld \& Senik, 2010; Solt, 2019), have less

\footnotetext{
${ }^{2}$ As noted in Section 4, for reasons of perfect collinearity it is not possible to simultaneously include terms for reference position and reference mobility when the reference group is defined by class origin for both terms.
} 
easily accessible welfare states (Kuitto, 2018) and exhibit lower levels of economic development. Thus, individuals in Eastern Europe face greater economic uncertainty and a greater risk of poverty. As explained above, class destination and origin mitigates or exacerbates such economic risks, and should therefore have greater effects in Eastern than in Western Europe.

Second, prior to Eastern Europe's economic transition to capitalism, working in white-collar professions did not result in markedly better economic outcomes than blue-collar jobs. However, during the transition period, blue-collar and manual labour became relatively more disadvantaged over time (Gerber \& Hout, 1998; Slomczyński \& Shabad, 1996). Thus, social classes are more stratified today than previously, which makes differences between one's class destination and one's class origin more obvious. Consequently, we expect the effect of own intergenerational class mobility to be larger in Eastern than in Western Europe.

Third, Eastern European countries today exhibit, net of overall shifts in the class distribution, a tighter association between class origin and destination than much of the West (Paskov \& Bukodi, 2018). In such low social fluidity environments, reference class mobility provides individuals with a stronger signal about one's relative performance than environments where the origin-destination association is weaker. We thus also expect the effect of reference class mobility to be stronger in the East.

\section{$\underline{\text { 3. Previous findings }}$}

Hadjar \& Samuel (2015) use British and Swiss data, and a collapsed Erikson-GoldthorpePortocarero (EGP) class scheme. For the UK, they observe a slight negative effect of being found in the unskilled compared to the upper service class, and a marginal negative effect of intergenerational downward mobility. However, they cannot replicate these findings for Switzerland. Moreover, they do not control for class origin. Therefore, their estimates of the effects of intergenerational class mobility and destination may be driven by this omission. 
Chan (2018) also utilizes British data and a collapsed EGP class scheme. Results show that those in the working class are less satisfied than those in the salariat, and that those who have been intergenerationally mobile report intermediate levels of satisfaction. Unfortunately, by using dummies for each mobility trajectory, it is indeterminate as to whether class mobility effects or class origin effects drive these results.

Lipps \& Oesch (2018) consider Germany and Switzerland. They also use a collapsed EGP class scheme. They exclusively investigate the effects of class destination on life satisfaction and find that those in the lower working class report 0.9 to 0.2 points lower life satisfaction than those in the upper-middle class. This class gradient runs roughly homogenously across intermediate classes.

Iveson \& Deary (2017) utilize Scottish cohort data and the General Registrar's occupational classification. Focussing on the elderly, they also detect a small effect of class destination on life satisfaction, though fail to find robust class mobility effects. However, in their social mobility analyses they do not control for the separate effects of class destination and origin. Their mobility estimates may thus be biased.

By using diagonal reference models, Marshall \& Firth (1999) are the first to control for both class destination and origin when estimating mobility effects. Using a collapsed EGP class scheme, they utilize data on 13 European countries. They do not explicitly report their estimates of class position, but find that class destination matters up to 5 times more than class origin. The study consistently finds no life satisfaction effect of class mobility. However, they include no controls for possible confounders.

Haller \& Hadler (2006) investigate the effect of subjective social class on life satisfaction using World Values Survey data. Although subjective social class is different from occupational class, it is interesting that they find significantly varying effects across regions: In traditionally capitalist countries they find weak effects, while in post-socialist countries effects are strong. 
Zhao et al. (2017) use happiness instead of life satisfaction data and focus on China. Using diagonal reference models and a collapsed EGP scheme, they detect a small class position gradient in happiness. However, they do not find any effects of intergenerational class mobility.

There is also a small literature on intergenerational social mobility and life satisfaction that does not conceptualize social mobility as class mobility but rather as income mobility (Dolan \& Lordan, 2013), educational mobility (Nikolaev \& Burns, 2014; Schuck \& Steiber, 2017), or status mobility (Clark \& D’Angelo, 2015; Nikolaev \& Burns, 2014; Zang \& de Graaf, 2016). Most of these studies report associations that give a positive effect of upward mobility and negative effect of downward mobility, but fail to account for potential reference effects.

Thus, there is previous evidence in favour of $\mathbf{H 1}$, i.e. that higher class destinations improve life satisfaction. The evidence is less clear regarding $\mathbf{H 2}$ (on class origin) and $\mathbf{H 3}$ (on class mobility). No previous study investigated the effects of reference class position or reference class mobility on life satisfaction.

\section{Data and methods}

We use waves 1-5 of the European Social survey (ESS), which covers the period 2002-2010 with repeated cross-sections. The 32 European countries included are roughly evenly split between Western and Eastern European post-socialist countries. A list of countries in each group can be found in the Appendix.

Our dependent variable are responses to the question "All things considered, how satisfied are you with your life as a whole nowadays?", which are scored on a scale from 0 (dissatisfied) to 10 (satisfied). See Diener, Inglehart, \& Tay (2013) for a review on the validity of this measure. We treat life satisfaction as cardinal since previous research has shown that ratios of coefficients obtained from ordered logit or probit models do not differ much to those from OLS models (Ferrer-i-Carbonell \& Frijters, 2004; Riedl \& Geishecker, 2014). 
To operationalize social class, we use the European Socio-Economic classification (ESeC), which was explicitly developed for comparative research across Europe (Rose et al., 2009). Unlike previous studies, we do not collapse the 9-category class scheme, allowing for more fine-grained analyses. We assume that most social classes are hierarchically ordered, primarily with respect to their employment relations. Moreover, within occupations that share the same type of employment relation, we assume a hierarchical ordering from blue-collar to white-collar work. However, we do not believe that the self-employed classes can be placed into a hierarchical ordering - at least when it comes to the stratification of life satisfaction by social class. Section 4.1 provides descriptive evidence that shows a gradient in life satisfaction following the assumed ordering along employed classes, from which the self-employed appear exempt. We therefore exclude the self-employed from analyses that require assumptions about the ordering of classes.

Table 1. Description and hierarchical ordering of ESeC Social Classes (adapted from Rose et al., 2009)

\begin{tabular}{|c|c|c|c|}
\hline & ESeC Class & Common term & Employment regulation \\
\hline I & $\begin{array}{l}\text { Large employers, higher grade professional, } \\
\text { administrative and managerial occupations }\end{array}$ & Higher salariat & Service relationship \\
\hline II & $\begin{array}{l}\text { Lower grade professional, administrative and } \\
\text { managerial occupations and higher grade } \\
\text { technician and supervisory occupation }\end{array}$ & Lower salariat & $\begin{array}{l}\text { Service relationship } \\
\text { (modified) }\end{array}$ \\
\hline III & Intermediate occupations & Higher grade white collar workers & Mixed \\
\hline IV & $\begin{array}{l}\text { Lower supervisory and lower technician } \\
\text { occupations }\end{array}$ & Higher grade blue collar workers & Mixed \\
\hline $\mathrm{V}$ & Lower services, sales and clerical occupations & Lower grade white collar workers & Labour contract (modified) \\
\hline VI & Lower technical occupations & Skilled workers & Labour contract (modified) \\
\hline VII & Routine occupations & Semi- and non-skilled workers & Labour contract \\
\hline SEI & $\begin{array}{l}\text { Small employers and self-employed } \\
\text { occupations (excl. agriculture.) }\end{array}$ & Petit bourgeoisie or independents & - \\
\hline SEII & Self-employed occupations (agriculture) & Petit bourgeoisie or independents & - \\
\hline
\end{tabular}

Note: Classes SEI and SEII are assumed to fall outside any hierarchical ordering. The long-term unemployed and those that never worked are not included in this study.

We construct the "full" version of ESeC based on information on 3-digit ISCO-88 codes, employment status, number of employees and supervisory functions. When a person with a particular ISCO code has missing data on any supplementary variables, we assign the class that is assigned most often (i.e. the observed weighted mode in class destination) for those individuals with the same ISCO code but no missings on the additional variables. We use the same procedure 
for origin class, where the observed mode of class origin is decisive. This is a refinement of the official "simplified" version of ESeC as it takes into account intergenerational differences in class distributions by occupational codes. To determine class origin we take parental occupational information when respondents were 14 years old. We use parental ISCO codes provided by Ganzeboom (2014) and apply the "dominance approach" (Erikson, 1984), which assigns the higher class when father's and mother's class position differ. Counts and shares for the distributions of class destination and origin are given in the Appendix.

For our selection of controls we draw on Angrist \& Pischke's (2008) distinction between "good" controls that are determined prior or independently of the determination of social class (henceforth, predetermined"), and "bad" controls which are mediators of the effects of social class on life satisfaction. In our set of predetermined controls, we include dummies for NUTS1 regions, wave dummies, gender, age(-squared), ethnic minority status, and country of birth. In line with our theoretical framework, we treat the logarithm of real household income ${ }^{4}$ and unemployment as mediators of the effect of class destination. Self-assessed religiousness, marital status, place of domicile (urban/rural dummy), and years of education(-squared) are ambiguous concerning their status as good or bad controls: Class origin determines education, which in turn determines class destination (e.g. Bukodi \& Goldthorpe, 2016). Education is thus a bad control vis-à-vis class origin, but a good control vis-à-vis class destination. Since religiousness, place of domicile and marital status are partially determined by class origin, they are mediators of the effect of class origin. However, we do not know the causal direction of these variables with respect to class destination and are thus agnostic whether they are good or bad controls when assessing its effect on life satisfaction. Therefore, we always present results with and without these ambiguous controls,

\footnotetext{
${ }^{3}$ With " $Z$ is predetermined with respect to $X$ ", we mean that the value of $Z$ is determined causally prior to $X$, and thus cannot mediate any effects X might have on a further variable $Y$. Therefore, a "predetermined" variable Z, is a "good" control when estimating the effect of $\mathrm{X}$ on $\mathrm{Y}$.

${ }^{4}$ To derive individual incomes we took, for each wave and country, mid-points from the show cards on income in the ESS questionnaire and converted these values into 2010 Euros. For the highest income category, where no upper bound is given, we use the method of Hout (2004, see equation 1).
} 
noting that the correct effect associated with class destination should fall between these estimates.

Descriptive statistics for all variables are in the Appendix.

To test $\mathbf{H} 1$ and $\mathbf{H} 2$, i.e. those relating to the direct effects of class destination and origin, we use OLS models of the following form:

$$
L S_{i}=\alpha+\delta_{d} D E S T_{d}+\theta_{o} O R I G_{o}+\boldsymbol{\beta} \boldsymbol{X}+\varepsilon_{i}
$$

$D E S T_{d}$ and $O R I G_{o}$ are dummies for class destination $d$ and class origin $o$ of respondent $i$. $\boldsymbol{\beta} \boldsymbol{X}$ represents controls and their parameters.

To test for class mobility effects, we use diagonal reference models. When mobility is defined as the difference between class destination and origin, no mobility effects can be estimated with standard OLS given the perfect collinearity of such a variable with destinations and origins (Sobel, 1981; van der Waal, Daenekindt, \& de Koster, 2017). Diagonal reference models circumvent this problem by modelling the dependent variable as a function of the population means of those that were immobile and of either the same class origin or destination as the respondent (those " $\mathrm{n}$ the diagonal').

Formally, we estimate models of the following form:

$$
L S_{i}=\alpha+p \mu_{d d}+(1-p) \mu_{o o}+\gamma_{1} \text { DIST }_{i}+\gamma_{2} \text { REFPOS }_{\text {oct }}+\gamma_{3} \text { REFMOB }_{d c t}+\boldsymbol{\beta} \boldsymbol{X}+\varepsilon_{i}
$$

Here, $\mu_{d d}$ and $\mu_{o o}$ are parameters associated with those on the diagonal and of the same class destination $\left(\mu_{d d}\right)$ or class origin $\left(\mu_{o o}\right)^{5}$ as respondent $i$. We will refer to our estimates of $\mu$ as estimates of "class position". Parameter $p$ is an estimated weight that represents the relative importance of destinations $(p)$ and origins $(1-p)$. In robustness analyses, we let these weights themselves be conditional on destinations and origins, i.e. we replace $p$ with respectively $p_{d}$ or $p_{o}$ in equation (2).

\footnotetext{
${ }^{5} \mu_{d d}$ and $\mu_{o o}$ can respectively be written as $D E S T_{d} \delta_{d}$ and $O R I G_{o} \delta_{o}$, where $\delta_{d}$ and $\delta_{o}$ are parameters. We hence estimate the class position effects of those on the diagonal (i.e. when $d=o$ ) by constraining the origin and destination effects to equal (cf. Sobel, 1981, p.898).
} 
$D I S T_{i}, R_{E F P O S_{i o c t}}$, and REFMOB ${ }_{i d c t}$ are measures of own class mobility, reference position and reference mobility, respectively.

We measure own class mobility using the difference between class origin and destination $\left(D I S T_{i}=\right.$ $\left.O R I G_{i}-D E S T_{i}\right)$. Class I is assigned the value 1 , Class II is assigned the value 2 , etc. Thus, more positive values on DIST imply that individuals are more upwardly mobile, while more negative values imply that individuals are more downwardly mobile. We also separately investigate the effects of the number of classes moved up or down. Since own class mobility is determined by both class destination and class origin, it is unclear whether variables that are bad controls with respect to class origin but good controls concerning class destination (e.g. education) should be included. It is also unclear whether unemployment and income should be considered mediators of a class mobility effect. We therefore give results with the full set of controls, as well as results when including controls that are predetermined with respect to class origin.

We define our measure of reference position as the average class position of those in the reference group:

$$
\operatorname{REFPOS}_{o c t}=\frac{\sum_{j \in P O S_{o c t}} w_{j} D E S T_{j}}{\sum_{j \in P_{\text {Oct }}} w_{j}}
$$

Where $P O S_{\text {oct }}$ is the set of individuals indexed by $j$, who are different from respondent $i$, observed in the same wave, country, class origin and who are up to five years younger or older than respondent $i . w_{j}$ is the combined ESS post-stratification and population weight associated with respondent $j$. Since lower values on DEST denote hierarchically superior classes, lower values on REFPOST indicate that those in the reference group come from more advantaged classes.

Analogously, our measure of reference mobility is defined as the average class mobility of those in the reference group:

$$
R E F M O B_{d c t}=\frac{\sum_{j \in M O B_{d c t}} w_{j} D I S T_{j}}{\sum_{j \in M O B_{d c t}} w_{j}}
$$


$M O B_{d c t}$ is the set of individuals who are different from the respondent $i$, observed in the same wave, country, class destination ${ }^{6}$ and are between five years younger or older than respondent $i$. Our measure of reference mobility thus has the same scale as our variable for own mobility. When considering reference effects, we assume that all control variables are predetermined with respect to reference class and reference mobility and are thus good controls. ${ }^{7}$

We also ran models in which the reference groups were defined independently of class origin and class destination. However, in our preferred specifications with the full set of controls, all of these models yielded insignificant and very small coefficients. Indeed, and as will become clear in Section 5, we only find significant effects for reference mobility where the reference group is restricted to those of one's destination class - i.e. to the people who are particularly likely to be the immediate colleagues of individuals.

Table 3. Summary of methodological choices

\begin{tabular}{lll}
\hline Quantity of interest & Type of model & Preferred set of controls \\
\hline Own class destination & OLS & "Predetermined" / "More demographics" \\
Own class origin & OLS & "Predetermined" \\
Own class mobility & DRM & "Predetermined" / "Full" \\
Reference class position & DRM/OLS & "Full" \\
Reference class mobility & DRM/OLS & "Full" \\
\hline
\end{tabular}

Note: "Full" controls include: Age(-squared), years of education(-squared), household size(-squared), Ln real HH income, unemployed, gender, ethnic minority, born in country, self-assessed religiosity, marital status, place of domicile (urban/rural), ESS round, NUTS I region. "More demographics" removes from the above: Ln real HH income and unemployed. "Predetermined" additionally removes from the above: Household size(-squared), selfassessed religiosity, marital status, place of domicile, and years of education.

All of our methodological choices are listed in Table 3, where we summarise which methods and which sets of controls are preferred for each quantity of interest. For diagonal reference models

\footnotetext{
${ }^{6}$ Defining a term for reference mobility such that the reference group is constituted by those of one's own class origin (i.e. the same reference group as used for reference position), would yield a term for reference mobility that is given by own class origin minus reference position $\left(R E F M O B_{o c t}=O R I G_{o}-R E F P O S_{o c t}\right)$. Reference mobility would then be perfectly collinear with reference position and own class origin and could therefore not be entered in a regression model.

7 It may be that reference class position or mobility have network effects, e.g. lowering the probability of unemployment. We thus also provide results with just predetermined controls.
} 
we use the "drm" Stata package (Kaiser, 2018). We apply post-stratification and population weights and cluster standard errors at the region-wave level.

\section{Results}

We start by examining the descriptive evidence presented in Figure 2. The top panel shows the full sample and a clear gradient in mean life satisfaction across social classes. Within each class destination we also observe some variation in mean life satisfaction across class origins.

The bottom panels show that mean life satisfaction in Eastern Europe is substantially lower than in Western Europe. Remarkably, in the East life satisfaction in destination Class I is even lower than mean life satisfaction of destination Class VII in the West. Moreover, the position of the selfemployed (SEI) and farmers (SEII) greatly differs across these European regions. In the East, these classes are the most satisfied of all, while no such pattern exists in the West. One reason for the high life satisfaction of the self-employed in Eastern Europe may be that following the collapse of socialism many who were in state-managerial positions entered careers as entrepreneurs (Slomczyński \& Shabad, 1996). This vindicates our view that the self-employed classes cannot be straightforwardly placed in a hierarchical ordering for the purpose of this study. Furthermore, class origin appears to play a smaller role in the West than in the East. This can be seen from the much greater variation in mean life satisfaction across class origins within each destination in Eastern when compared to Western Europe. Such greater variation is in line with our discussion in Section 3, where we expected own intergenerational class mobility to matter more in Eastern Europe.

However, these figures can neither show direct mobility effects nor indicate the presence of reference effects. They also do not net out the effects of confounders. Therefore, we now turn to our regression results. We start with our results for Western Europe and subsequently turn to the East. 


\section{Full sample}
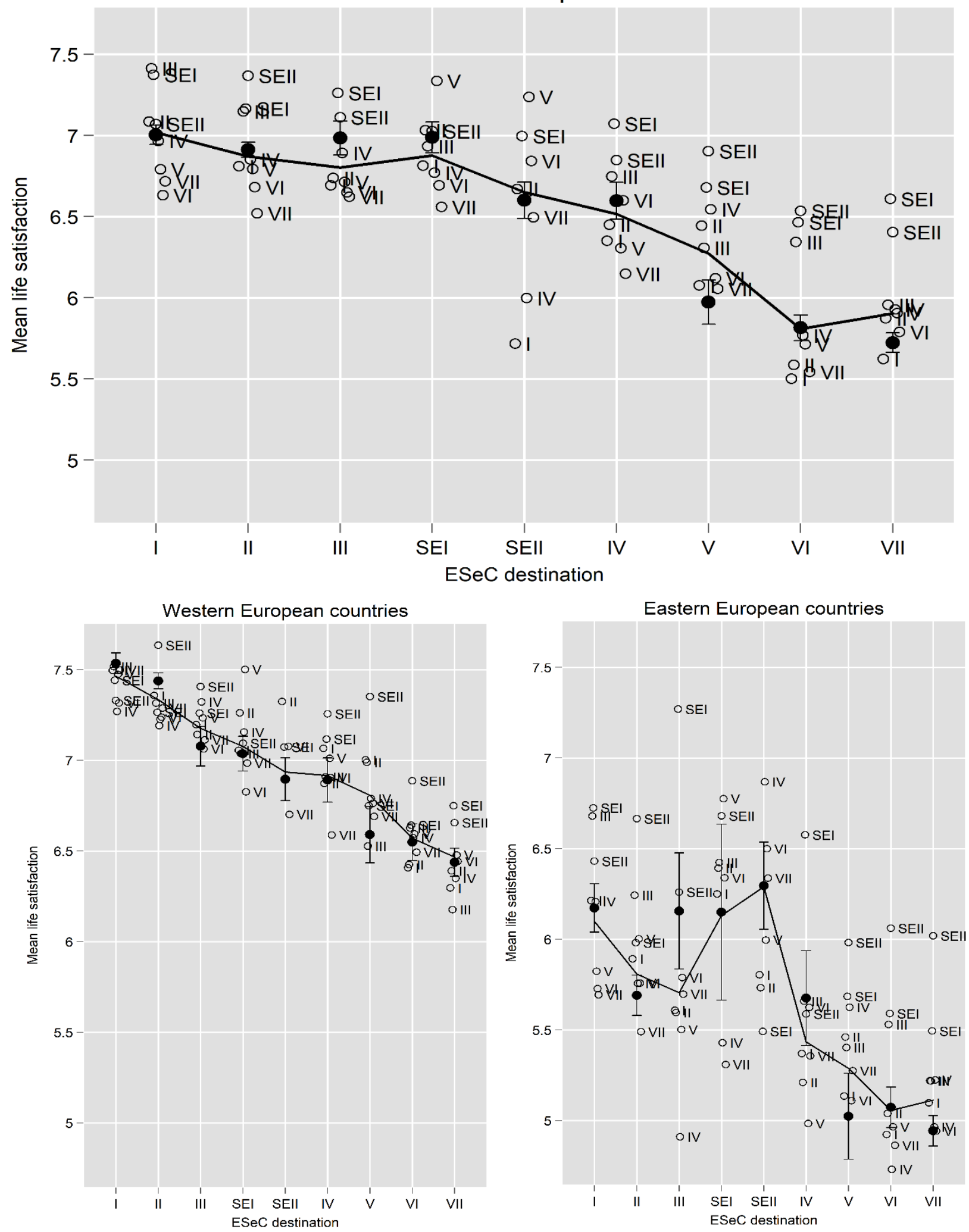

The line represents observed mean life satisfaction across social class destinations. Filled dots with $95 \%$-confidence intervals show mean life satisfaction for those with the same class origin and destination, i.e. the immobile. Hollow labelled dots represent mean life satisfaction within each destination across class origins. 


\subsection{Western Europe}

\subsubsection{Class destination and class origin}

Table 4 presents results for the effects of class destination and class origin in Western Europe. As we move from the first to the last column, we consecutively add additional controls. For both class destination and origin, we define Class I, i.e. the upper salariat, as the reference category and analyse whether life satisfaction is different in the other classes.

Table 4 Class position effects in Western Europe

\begin{tabular}{|c|c|c|c|c|c|}
\hline & (1) & (2) & (3) & (4) & (5) \\
\hline & $\begin{array}{c}\text { Region \& wave } \\
\text { FEs }\end{array}$ & Predetermined & Education & $\begin{array}{c}\text { More } \\
\text { demographics }\end{array}$ & $\begin{array}{l}\text { Unemployment } \\
\text { \& income }\end{array}$ \\
\hline Destination $=\mathrm{II}$ & $-0.132^{* * *}(0.035)$ & $-0.149^{* * *}(0.035)$ & $-0.131^{* * *}(0.037)$ & $-0.117^{* *}(0.036)$ & $-0.039(0.034)$ \\
\hline Destination=III & $-0.213^{* * *}(0.042)$ & $-0.253^{* * *}(0.043)$ & $-0.211^{* * *}(0.045)$ & $-0.180^{* * *}(0.045)$ & $-0.055(0.044)$ \\
\hline Destination $=\mathrm{IV}$ & $-0.519^{* * *}(0.054)$ & $-0.521^{* * * *}(0.054)$ & $-0.442^{* * *}(0.056)$ & $-0.421^{* * *}(0.056)$ & $-0.239^{* * *}(0.055)$ \\
\hline Destination $=\mathrm{V}$ & $-0.594^{* * *}(0.057)$ & $-0.630^{* * *}(0.058)$ & $-0.552^{* * *}(0.061)$ & $-0.518^{* * *}(0.060)$ & $-0.291^{* * *}(0.057)$ \\
\hline Destination $=\mathrm{VI}$ & $-0.752^{* * *}(0.060)$ & $-0.742^{* * *}(0.060)$ & $-0.628^{* * *}(0.065)$ & $-0.592^{* * *}(0.063)$ & $-0.306^{* * *}(0.061)$ \\
\hline Destination $=$ VII & $-0.889^{* * *}(0.057)$ & $-0.895^{* * *}(0.056)$ & $-0.778^{* * *}(0.060)$ & $-0.700^{* * *}(0.059)$ & $-0.397^{* * *}(0.058)$ \\
\hline Destination $=$ SEI & $-0.343^{* * *}(0.055)$ & $-0.326^{* * *}(0.055)$ & $-0.253^{* * *}(0.057)$ & $-0.247^{* * *}(0.055)$ & $-0.119^{* *}(0.052)$ \\
\hline Destination $=$ SEII & $-0.586^{* * *}(0.099)$ & $-0.577^{* * *}(0.101)$ & $-0.465^{* * *}(0.101)$ & $-0.500^{* * *}(0.098)$ & $-0.262^{* *}(0.096)$ \\
\hline Origin $=\mathrm{II}$ & $-0.007(0.037)$ & $-0.001(0.036)$ & $0.009(0.037)$ & $-0.003(0.038)$ & $0.021(0.037)$ \\
\hline Origin $=\mathrm{III}$ & $-0.058(0.053)$ & $-0.061(0.052)$ & $-0.041(0.053)$ & $-0.048(0.050)$ & $-0.028(0.049)$ \\
\hline Origin $=\mathrm{IV}$ & $-0.068(0.047)$ & $-0.060(0.047)$ & $-0.034(0.047)$ & $-0.075^{+}(0.046)$ & $-0.038(0.046)$ \\
\hline Origin $=\mathrm{V}$ & $-0.036(0.056)$ & $-0.028(0.057)$ & $0.003(0.057)$ & $-0.015(0.055)$ & $0.027(0.054)$ \\
\hline Origin $=\mathrm{VI}$ & $-0.061(0.046)$ & $-0.047(0.047)$ & $-0.002(0.048)$ & $-0.046(0.046)$ & $0.026(0.045)$ \\
\hline Origin $=$ VII & $-0.142^{* *}(0.047)$ & $-0.122^{* *}(0.047)$ & $-0.070^{+}(0.048)$ & $-0.106^{* *}(0.048)$ & $-0.041(0.047)$ \\
\hline Origin $=$ SEI & $-0.009(0.048)$ & $0.000(0.048)$ & $0.027(0.048)$ & $-0.008(0.048)$ & $0.025(0.047)$ \\
\hline Origin=SEII & $0.143^{* *}(0.055)$ & $0.154^{* *}(0.055)$ & $0.204^{* * *}(0.056)$ & $0.085^{+}(0.056)$ & $0.101^{*}(0.055)$ \\
\hline Fixed effects & YES & YES & YES & YES & YES \\
\hline Predet. demogr. & $\mathrm{NO}$ & YES & YES & YES & YES \\
\hline Education & $\mathrm{NO}$ & $\mathrm{NO}$ & YES & YES & YES \\
\hline More demogr. & $\mathrm{NO}$ & $\mathrm{NO}$ & $\mathrm{NO}$ & YES & YES \\
\hline UE \& income & $\mathrm{NO}$ & $\mathrm{NO}$ & $\mathrm{NO}$ & $\mathrm{NO}$ & YES \\
\hline Log likelihood & -163853 & -163650 & -163582 & -162311 & -160933 \\
\hline AIC & 327895 & 327498 & 327366 & 324841 & 322089 \\
\hline $\mathrm{N}$ & 76965 & 76965 & 76965 & 76965 & 76965 \\
\hline
\end{tabular}

Column (2) estimates an upper bound for the total class effect. Here we only control for variables that are predetermined with respect to class destination and class origin, i.e. gender, ethnic minority 
status, age, and citizenship. For class destination, the difference between Class I and Class VII is 0.90 on the life satisfaction scale and statistically significant. This a very substantial effect, far exceeding that of being of an ethnic minority (=-0.35; not shown in table), which is the next largest coefficient in this model. Gaps between the classes are generally similar, roughly equalling 0.1 , though there is a larger gap between Class III and IV $(=0.27)$. The self-employed classes also show lower life satisfaction than those in the upper salariat placing them in the middle of the employed class hierarchy. These results for Western Europe are very much in line with those of Lipps \& Oesch (2018) for Germany and Switzerland.

We observe very limited effects for class origins. This aligns with the descriptive impression of Figure 2. The only significant coefficients are those for Classes VII (=-0.12; semi-skilled and unskilled workers) and SEII (=0.15; self-employed in agriculture). The latter effect is striking, since it implies that children of farmers are more satisfied than those whose parents are from the presumably most socio-economically advantaged social class.

In Column (3) we add education. As explained in Section 3, education is a good control with respect to class destination, but a mediator vis-à-vis class origin. In our models, the effect of education is generally positive $(=0.06[-0.002] \text { for years[-squared }]^{8}$; not shown in table). The inclusion of education causes the coefficient for class origin VII to be substantially reduced. This implies that most of the negative effects of growing up in the working class is mediated by education.

In Column (4) we add additional demographics including place of residence, marital status, religiousness and household size. These are bad controls concerning class origin and ambiguous concerning class destination. Apart from reducing the destination class gradient in life satisfaction, the addition of these variables turns the positive effect of having been raised by farmers (SEII) marginally insignificant. This is driven by place of residence as measured by an urban/rural dummy:

\footnotetext{
${ }^{8}$ Therefore, the marginal effect of years of education becomes negative at 22 years. It takes a $\mathrm{PhD}$ to make education dissatisfying.
} 
Children of farmers are more likely to live on the countryside, which appears to improve their satisfaction with life.

In Column (5) we add unemployment and the log of household income ${ }^{9}$. These are mediators of class destination. Compared to Column (4), the overall gradient in class destination is reduced by about a third. However, there is no statistically significant difference between Classes II and III versus Class I. This suggests that most of the difference between Classes I to III are driven by current income and unemployment rather than other benefits of Class I.

It is clear that there is a substantial gradient in life satisfaction across class destinations. Class origin, with the exception of having farmers as parents, has no significant effects in Western Europe when controlling for class destination. Therefore, these results largely corroborate $\mathbf{H 1}$ and partially contradict $\mathbf{H} 2$.

\subsubsection{Class mobility and reference classes}

Using diagonal reference models in Table 5 we now assess the effects of class mobility. Columns (1) and (3) show results with our set of predetermined controls, whereas Columns (2) and (4) include all available controls.

Our findings for class position are generally in line with those of Table 4: For the immobile with predetermined controls there is roughly a 1 point difference in life satisfaction between Classes I and VII. This is reduced to roughly 0.4 points when adding the full set of controls. Similarly, weight parameter $p$ is larger than 0.5 indicating the greater importance of class destination compared to class origin, which was already visible in Figure 2.

At baseline, we find no significant evidence for effects of intergenerational class mobility in Western Europe. Although in the expected direction, the coefficients for class mobility are insignificant. If the dissociative hypothesis was true, both moving up and down the social ladder

\footnotetext{
${ }^{9}$ Coefficients for unemployment and income are -1.00 and 0.35 , which is at the upper end of commonly reported estimates.
} 
would decrease life satisfaction. We therefore separate the effects of moving up and down in Columns (3) and (4). Again, all coefficients remain insignificant.

However, in Columns (5) to (8) we repeat these analyses, but now allow the weight parameter $p$ to also depend on class origins. We thus let the relative importance of class destination versus class origin in determining life satisfaction itself depend on where individuals originate. Now, when using the full set of controls, terms for own (downward) mobility are significant at the $1 \%$ level.

The result of Column (8) in particular, where we use all controls, implies loss aversion - a notion that has been extensively discussed by the mobility literature to explain mechanisms of intergenerational immobility (Breen \& Goldthorpe, 1997): While moving up has no effects beyond positional effects, there is a negative effect of downward class mobility. The estimates of Column (8) imply that a person coming from Class I and moving to Class VII can, holding all other variables constant, be expected to lose $0.456\left(=0.076^{*} 6\right)$ points on the $0-10$ life satisfaction scale ${ }^{10}$. In the Appendix, we verify this by allowing weights to depend on class destinations rather than class origins yielding similar results. Thus, we obtain some evidence corroborating $\mathbf{H 3}$ : Intergenerational class downward mobility indeed appears to negatively affect life satisfaction.

\footnotetext{
${ }^{10}$ The weight on class destination for those with class origin $=\mathrm{I}$ is constrained to 0. Following Sobel (1981), we constrain weights when estimates fall outside the interval $[0,1]$. Not constraining the weight resulted in $p_{I}=-0.002$ and yielded no change in the coefficients for class mobility. The same holds for $p_{I I I}$ in Column (6) where we otherwise obtain $p_{I I I}=1.084$.
} 


\begin{tabular}{|c|c|c|c|c|c|c|c|c|}
\hline & \multicolumn{4}{|c|}{ Standard } & \multicolumn{4}{|c|}{ Weights conditional on class origin } \\
\hline & $(1)$ & (2) & (3) & (4) & (5) & (6) & $(7)$ & $(8)$ \\
\hline & $\begin{array}{l}\text { Distance travelled } \\
\text { with } \\
\text { predetermined } \\
\text { controls }\end{array}$ & $\begin{array}{l}\text { Distance travelled } \\
\text { with full controls }\end{array}$ & $\begin{array}{l}\text { Distance travelled } \\
\text { up and down with } \\
\text { predetermined } \\
\text { controls }\end{array}$ & $\begin{array}{l}\text { Distance travelled } \\
\text { up and down with } \\
\text { full controls }\end{array}$ & $\begin{array}{l}\text { Distance travelled } \\
\text { with } \\
\text { predetermined } \\
\text { controls }\end{array}$ & $\begin{array}{l}\text { Distance travelled } \\
\text { with full controls }\end{array}$ & $\begin{array}{l}\text { Distance travelled } \\
\text { up and down with } \\
\text { predetermined } \\
\text { controls }\end{array}$ & $\begin{array}{l}\text { Distance travelled } \\
\text { up and down with } \\
\text { full controls }\end{array}$ \\
\hline Class $=I$ & $0.532^{* * *}(0.039)$ & $0.207^{* * *}(0.044)$ & $0.529^{* * *}(0.041)$ & $0.205^{* * *}(0.045)$ & $0.518^{* * *}(0.047)$ & $0.197^{* * *}(0.044)$ & $0.523^{* * *}(0.047)$ & $0.204^{* * *}(0.041)$ \\
\hline Class=II & $0.352^{* * *}(0.035)$ & $0.171^{* * *}(0.038)$ & $0.348^{* * *}(0.035)$ & $0.166^{* * *}(0.038)$ & $0.349^{* * *}(0.038)$ & $0.161^{* * *}(0.043)$ & $0.345^{* * *}(0.040)$ & $0.141^{* * *}(0.032)$ \\
\hline Class=III & $0.220^{* * *}(0.051)$ & $0.150^{* * *}(0.049)$ & $0.220^{* * *}(0.054)$ & $0.149^{* * *}(0.051)$ & $0.232^{* * *}(0.056)$ & $0.198^{* * *}(0.069)$ & $0.231^{* * *}(0.055)$ & $0.203^{* * *}(0.058)$ \\
\hline Class $=I V$ & $-0.103^{*}(0.054)$ & $-0.099^{*}(0.055)$ & $-0.103^{*}(0.056)$ & $-0.100^{*}(0.057)$ & $-0.101+(0.062)$ & $-0.106^{+}(0.073)$ & $-0.102^{+}(0.066)$ & $-0.122(0.117)$ \\
\hline Class $=\mathrm{V}$ & $-0.207^{* * *}(0.063)$ & $-0.110^{*}(0.062)$ & $-0.204^{* * *}(0.063)$ & $-0.107^{*}(0.061)$ & $-0.213^{* * *}(0.082)$ & $-0.132(0.118)$ & $-0.221^{* *}(0.090)$ & $-0.211^{*}(0.121)$ \\
\hline Class=VI & $-0.274^{* * *}(0.101)$ & $-0.070(0.080)$ & $-0.278^{* *}(0.114)$ & $-0.073(0.086)$ & $-0.243^{* * *}(0.066)$ & $-0.059(0.056)$ & $-0.240^{* * *}(0.072)$ & $-0.012(0.058)$ \\
\hline Class=VII & $-0.521^{* * *}(0.066)$ & $-0.249^{* * *}(0.059)$ & $-0.513^{* * *}(0.069)$ & $-0.240^{* * *}(0.061)$ & $-0.542^{* * *}(0.060)$ & $-0.260^{* * *}(0.061)$ & $-0.536^{* * *}(0.070)$ & $-0.202^{* * *}(0.066)$ \\
\hline $\mathrm{p}$ & $0.717^{*}(0.418)$ & $0.652^{* *}(0.282)$ & $0.727^{+}(0.490)$ & $0.659^{* *}(0.318)$ & & & & \\
\hline pI & & & & & $0.642^{* * *}(0.248)$ & $0.493^{+}(0.343)$ & $0.598^{* *}(0.274)$ & 0.000 (constr.) \\
\hline pII & & & & & $0.646^{* * *}(0.137)$ & $0.575^{*}(0.295)$ & $0.600^{* * *}(0.139)$ & $0.103(0.303)$ \\
\hline pIII & & & & & $0.867^{* * *}(0.198)$ & 1.000 (constr.) & $0.840^{* * *}(0.204)$ & $0.854^{* * *}(0.253)$ \\
\hline pIV & & & & & $0.558^{* * *}(0.162)$ & $0.620^{+}(0.427)$ & $0.563^{* * *}(0.204)$ & $0.696^{*}(0.385)$ \\
\hline $\mathrm{p}_{\mathrm{V}}$ & & & & & $0.605^{* * *}(0.183)$ & $0.597(0.590)$ & $0.634^{* *}(0.256)$ & $0.884^{* * *}(0.250)$ \\
\hline $\mathrm{pVI}$ & & & & & $0.440^{* * *}(0.156)$ & $0.249(0.327)$ & $0.473^{* *}(0.231)$ & $0.370^{+}(0.243)$ \\
\hline pVII & & & & & $0.551^{* * *}(0.125)$ & $0.472+(0.346)$ & $0.584^{* * *}(0.194)$ & $0.685^{* *}(0.269)$ \\
\hline \#Classes moved & $0.034(0.072)$ & $0.025(0.022)$ & & & $0.056^{+}(0.042)$ & $0.034^{* * *}(0.012)$ & & \\
\hline \#Classes up & & & $0.019(0.084)$ & $0.010(0.025)$ & & & $0.048(0.048)$ & $0.008(0.016)$ \\
\hline \#Classes down & & & $-0.051(0.084)$ & $-0.042^{+}(0.026)$ & & & $-0.066^{+}(0.049)$ & $-0.076^{* * *}(0.018)$ \\
\hline Fixed effects & YES & YES & YES & YES & YES & YES & YES & YES \\
\hline Predet. demogr. & YES & YES & YES & YES & YES & YES & YES & YES \\
\hline Education & $\mathrm{NO}$ & YES & $\mathrm{NO}$ & YES & NO & YES & NO & YES \\
\hline More demogr. & $\mathrm{NO}$ & YES & $\mathrm{NO}$ & YES & $\mathrm{NO}$ & YES & $\mathrm{NO}$ & YES \\
\hline UE \& income & NO & YES & NO & YES & NO & YES & NO & YES \\
\hline Log likelihood & -114135 & -112163 & -114131 & -112159 & -114126 & -112154 & -114126 & -112149 \\
\hline AIC & 228454 & 224535 & 228448 & 224528 & 228448 & 224527 & 228450 & 224518 \\
\hline $\mathrm{N}$ & 55006 & 55006 & 55006 & 55006 & 55006 & 55006 & 55006 & 55006 \\
\hline
\end{tabular}

$+\mathrm{p}<0.20,{ }^{*} \mathrm{p}<0.10,{ }^{* *} \mathrm{p}<0.05,{ }^{* * *} \mathrm{p}<0.01$. Region- and wave-clustered standard errors in parentheses. 
Table 6 presents the effects of reference class position and reference mobility. Since reference effects operate independently of individual-level variables, unemployment and income should now be considered "good" controls. We use mean class position of people in the reference group as a measure of reference class position (equation 3), and mean distance travelled by those in the reference group (equation 4) as our measure of reference mobility. Reference position is insignificant throughout, thus contradicting H4a. However, reference mobility is initially marginally insignificant $(p=0.10)$ in Column (1), and then turns significant at the $1 \%$ level in Column (2). The negative coefficient implies that greater upward (downward) mobility of those in an individual's reference group has a negative (positive) effect on an individual's life satisfaction. This is similar to the negative reference effects found in the literature on relative income and in line with $\mathbf{H} \mathbf{4} \mathbf{b}$. Since there are seven hierarchically ordered classes, our measure of reference mobility is theoretically bounded between -6 and 6 but has an observed range of -5.02 and 5.25 , and a standard deviation of 1.43 . Thus, given that our coefficient estimate is -0.08 , moving from the lowest observed value of reference mobility to the highest value would imply a decrease in life satisfaction by 0.84 points on a $0-10$ scale. Alternatively, a one standard deviation increase implies a 0.12 point decrease in life satisfaction.

In Columns (3) and (4), we disentangle whether these results differ between those that performed better or worse than their reference group. We do so by entering separate terms indicating whether the respondent has a class position above or below her reference group, and separate terms for cases in which the respondent was either more or less mobile than her reference group. We find that the negative effect of reference mobility is stronger when the respondent outperformed her reference group (i.e. has been more upwardly or less downwardly mobile). Though initially counterintuitive, this result has a simple explanation: By construction, those from lower class origins are more likely to be more upwardly mobile than their reference group. Thus, our result suggests that the effect of reference mobility is stronger for those from lower class origins. To verify this intuition, we estimate origin-specific effects of reference mobility (see Appendix). We 
indeed find a gradient in the effect of reference mobility with the effect being largest for those of Class origin VII (=-0.11) and smallest for those of Class origin III $(=-0.03)$.

Table 6 Reference class effects in Western Europe

\begin{tabular}{|c|c|c|c|c|}
\hline & (1) & (2) & (3) & (4) \\
\hline & $\begin{array}{l}\text { Distances, with } \\
\text { predetermined } \\
\text { controls }\end{array}$ & $\begin{array}{l}\text { Distances, with } \\
\text { full controls }\end{array}$ & $\begin{array}{l}\text { Distances in either } \\
\text { direction, with } \\
\text { predetermined } \\
\text { controls }\end{array}$ & $\begin{array}{l}\text { Distances in either } \\
\text { direction, with full } \\
\text { controls }\end{array}$ \\
\hline Class $=\mathrm{I}$ & $0.573^{* * *}(0.077)$ & $0.331^{* * *}(0.075)$ & $0.559^{* * * *}(0.081)$ & $0.317^{* * * *}(0.079)$ \\
\hline Class $=\mathrm{II}$ & $0.386^{* * *}(0.061)$ & $0.261^{* * *}(0.057)$ & $0.385^{* * *}(0.065)$ & $0.259^{* * *}(0.062)$ \\
\hline Class $=$ III & $0.238^{* * * *}(0.062)$ & $0.204^{* * *}(0.054)$ & $0.249^{* * * *}(0.073)$ & $0.213^{* * *}(0.059)$ \\
\hline Class $=\mathrm{IV}$ & $-0.090^{+}(0.055)$ & $-0.079^{+}(0.058)$ & $-0.072^{+}(0.055)$ & $-0.058(0.055)$ \\
\hline Class $=\mathrm{V}$ & $-0.228^{* * * *}(0.070)$ & $-0.158^{* *}(0.067)$ & $-0.221^{* * * *}(0.070)$ & $-0.151^{* *}(0.070)$ \\
\hline Class $=\mathrm{VI}$ & $-0.295^{* * * *}(0.101)$ & $-0.158^{*}(0.094)$ & $-0.306^{*}(0.173)$ & $-0.166^{+}(0.110)$ \\
\hline Class $=\mathrm{VII}$ & $-0.584^{* * * *}(0.101)$ & $-0.401^{* * * *}(0.086)$ & $-0.593^{* * *}(0.131)$ & $-0.414^{* * * *}(0.094)$ \\
\hline $\mathrm{p}$ & $0.689^{*}(0.392)$ & $0.675^{* *}(0.279)$ & $0.745(0.788)$ & $0.705^{* *}(0.319)$ \\
\hline \#Classes moved & $0.062(0.077)$ & $0.044(0.036)$ & & \\
\hline Ref. class position & $-0.050^{+}(0.032)$ & $-0.017(0.032)$ & & \\
\hline Ref. class mobility & $-0.054^{+}(0.033)$ & $-0.082^{* * *}(0.031)$ & & \\
\hline \#Classes moved up & & & $0.058(0.152)$ & $0.049(0.044)$ \\
\hline \#Classes moved down & & & $-0.048(0.150)$ & $-0.037(0.043)$ \\
\hline Ref. class position (resp. is worse) & & & $-0.043(0.038)$ & $-0.011(0.035)$ \\
\hline Ref. class position (resp. is better) & & & $-0.045^{+}(0.033)$ & $-0.012(0.032)$ \\
\hline Ref. class mobility (resp. is worse) & & & $-0.023(0.036)$ & $-0.049^{+}(0.033)$ \\
\hline Ref. class mobility (resp. is better) & & & $-0.085^{* *}(0.041)$ & $-0.115^{* * *}(0.037)$ \\
\hline Fixed effects & YES & YES & YES & YES \\
\hline Predet. demographics & YES & YES & YES & YES \\
\hline Education & NO & YES & $\mathrm{NO}$ & YES \\
\hline More demographics & NO & YES & $\mathrm{NO}$ & YES \\
\hline Unemployment \& income & NO & YES & $\mathrm{NO}$ & YES \\
\hline Log likelihood & -114095 & -112122 & -114014 & -112041 \\
\hline AIC & 228379 & 224456 & 228223 & 224301 \\
\hline $\mathrm{N}$ & 54990 & 54990 & 54949 & 54949 \\
\hline
\end{tabular}

$+\mathrm{p}<0.20,{ }^{*} \mathrm{p}<0.10,{ }^{* *} \mathrm{p}<0.05,{ }^{* * *} \mathrm{p}<0.01$. Region- and wave-clustered standard errors in parentheses.

We thus reject $\mathbf{H} 4 \mathbf{a}$ and corroborate $\mathbf{H} 4 \mathbf{b}$ : While there are clear negative effects from reference mobility (especially for those of lower class origins), the effects from reference position are either nil or even positive. These reference effects are robust to letting weight $p$ be dependent on class destination or origins. We also successfully verify that our results for reference effects are robust to using OLS rather than diagonal reference models (see Appendix for both). 
Notice that terms for own mobility are again insignificant in Table 6. However, like above, they become significant in the equivalent Appendix tables that let weights be specific to class origin or class destination, thus reconfirming $\mathbf{H 3}$. Nevertheless, in these estimates, the effect of own upward mobility is much more positive. This suggests that the term for upward own mobility in Table 5 was picking up the uncontrolled-for negative effect of upward reference mobility and was thus biased. Therefore, our result of loss aversion in own class mobility is not robust.

\subsection{Eastern Europe}

\subsubsection{Class destination and class origin}

Table 7 presents our results for class destination and origin in Eastern Europe. We again find a substantial effect of class destination: Those in Class VII report on average 0.66 points lower levels of life satisfaction than those in Class I, when including all controls that are predetermined with respect to class destination (Column (3)). This is somewhat smaller than the effect size we find for Western Europe and thus surprising in light of the theoretical discussion in Section 2. However, those in the upper salariat (Class I) continue to show higher life satisfaction than those in Classes II and III even after accounting for unemployment and income (Column (5)). Indeed, very little of the class destination gradient is explained via unemployment and income in Eastern Europe (compare Columns (5) and (6)). Therefore characteristics of class destination other than current income and unemployment may matter much more in the East. Moreover, the self-employed (SEI) enjoy higher relative levels of life satisfaction than in Western Europe (in line with Figure 2) ${ }^{11}$. While in the West being self-employed has a similar effect as being in one of the intermediate occupations (Classes III and IV), in Eastern Europe the effect is similar to that of the upper salariat.

A further difference to Western Europe are the consistently significant class origin effects. When exclusively including predetermined controls, dummies for almost all non self-employed origin classes are negative and significant. Their coefficients are similar, indicating that there is a clear

\footnotetext{
11 The conditional life satisfaction of those in Class destination SEII is much lower than would be expected from Figure 2. As discussed below, the high life satisfaction of this group seems to be entirely driven by class origin.
} 
advantage to having parents in the upper salariat, but that no further gradient exists. Adding additional controls in column (3) to (6) shows that the advantage of having parents in the upper salariat is mediated by education, income and employment status. Individuals with self-employed parents or farmers do not follows this pattern. Instead, they show a similar or even higher life satisfaction as those whose parents are from the upper salariat.

Table 7 Class position effects in Eastern Europe

\begin{tabular}{|c|c|c|c|c|c|}
\hline & (1) & (2) & (3) & (4) & (5) \\
\hline & $\begin{array}{c}\text { Region \& wave } \\
\text { FEs }\end{array}$ & Predetermined & Education & $\begin{array}{c}\text { More } \\
\text { demographics }\end{array}$ & $\begin{array}{l}\text { Unemployment } \\
\text { \& income }\end{array}$ \\
\hline Destination $=\mathrm{II}$ & $-0.288^{* * *}(0.057)$ & $-0.276^{* * *}(0.055)$ & $-0.217^{* * *}(0.064)$ & $-0.229^{* * *}(0.067)$ & $-0.203^{* * *}(0.074)$ \\
\hline Destination $=$ III & $-0.432^{* * *}(0.110)$ & $-0.450^{* * *}(0.095)$ & $-0.332^{* * *}(0.102)$ & $-0.346^{* * *}(0.107)$ & $-0.291^{* * *}(0.104)$ \\
\hline Destination $=\mathrm{IV}$ & $-0.663^{* * *}(0.067)$ & $-0.647^{* * *}(0.067)$ & $-0.470^{* * *}(0.094)$ & $-0.494^{* * *}(0.102)$ & $-0.415^{* * *}(0.113)$ \\
\hline Destination $=\mathrm{V}$ & $-0.769^{* * *}(0.151)$ & $-0.808^{* * *}(0.129)$ & $-0.612^{* * *}(0.167)$ & $-0.594^{* * *}(0.169)$ & $-0.453^{* * *}(0.171)$ \\
\hline Destination $=\mathrm{VI}$ & $-0.992^{* * *}(0.054)$ & $-0.990^{* * *}(0.058)$ & $-0.736^{* * *}(0.085)$ & $-0.716^{* * *}(0.090)$ & $-0.570^{* * *}(0.101)$ \\
\hline Destination $=\mathrm{VII}$ & $-0.984^{* * *}(0.062)$ & $-0.935^{* * *}(0.058)$ & $-0.656^{* * *}(0.056)$ & $-0.659^{* * *}(0.065)$ & $-0.494^{* * *}(0.070)$ \\
\hline Destination $=$ SEI & $-0.135(0.131)$ & $-0.157(0.128)$ & $0.001(0.138)$ & $-0.023(0.141)$ & $-0.029(0.116)$ \\
\hline Destination=SEII & $-0.656^{* * *}(0.171)$ & $-0.639^{* * *}(0.177)$ & $-0.338^{+}(0.203)$ & $-0.379^{*}(0.208)$ & $-0.310^{+}(0.213)$ \\
\hline Origin $=\mathrm{II}$ & $-0.178^{* *}(0.086)$ & $-0.148^{*}(0.083)$ & $-0.134^{+}(0.083)$ & $-0.143^{*}(0.075)$ & $-0.132^{*}(0.076)$ \\
\hline Origin $=\mathrm{III}$ & $-0.233^{* *}(0.115)$ & $-0.212^{*}(0.107)$ & $-0.189^{*}(0.098)$ & $-0.195^{* *}(0.094)$ & $-0.183^{*}(0.101)$ \\
\hline Origin $=I V$ & $-0.299^{* *}(0.136)$ & $-0.185^{+}(0.130)$ & $-0.151(0.138)$ & $-0.163(0.129)$ & $-0.128(0.119)$ \\
\hline Origin $=\mathrm{V}$ & $-0.218^{* *}(0.106)$ & $-0.191^{*}(0.104)$ & $-0.148^{+}(0.104)$ & $-0.176^{*}(0.102)$ & $-0.146^{+}(0.107)$ \\
\hline Origin $=\mathrm{VI}$ & $-0.339^{* * *}(0.062)$ & $-0.198^{* * *}(0.056)$ & $-0.140^{* *}(0.059)$ & $-0.167^{* * *}(0.049)$ & $-0.134^{* *}(0.053)$ \\
\hline Origin $=$ VII & $-0.332^{* * *}(0.046)$ & $-0.150^{* * *}(0.039)$ & $-0.070^{*}(0.040)$ & $-0.090^{* *}(0.039)$ & $-0.010(0.042)$ \\
\hline Origin $=$ SEI & $-0.015(0.131)$ & $0.004(0.117)$ & $0.041(0.107)$ & $0.019(0.107)$ & $0.059(0.109)$ \\
\hline Origin $=$ SEII & $-0.153^{+}(0.096)$ & $0.092(0.098)$ & $0.193^{* *}(0.095)$ & $0.158^{*}(0.090)$ & $0.180^{* *}(0.080)$ \\
\hline Fixed effects & YES & YES & YES & YES & YES \\
\hline Predet. demogr. & $\mathrm{NO}$ & YES & YES & YES & YES \\
\hline Education & $\mathrm{NO}$ & $\mathrm{NO}$ & YES & YES & YES \\
\hline More demogr. & $\mathrm{NO}$ & $\mathrm{NO}$ & $\mathrm{NO}$ & YES & YES \\
\hline UE \& income & $\mathrm{NO}$ & $\mathrm{NO}$ & $\mathrm{NO}$ & $\mathrm{NO}$ & YES \\
\hline Log likelihood & -70535 & -70246 & -70179 & -69966 & -69485 \\
\hline AIC & 141156 & 140588 & 140459 & 140049 & 139091 \\
\hline $\mathrm{N}$ & 30808 & 30808 & 30808 & 30808 & 30808 \\
\hline
\end{tabular}

Overall, we find clear evidence in favour of $\mathbf{H 1}$ and $\mathbf{H} \mathbf{2}$ - both class destination and class origin are major determinants of life satisfaction in Eastern Europe. 


\subsubsection{Social mobility and reference classes}

The greater importance of class origin in Eastern Europe makes social mobility effects likely. To assess this, Table 8 presents our results using diagonal reference models. We indeed find a significantly positive own mobility effect: The number of classes travelled yields coefficients of 0.06 and 0.05 in Columns (1) and (2), respectively. Thus, a person who moves up from Class VII to Class I may gain 0.33 to 0.29 points in life satisfaction compared to a person who originates and remains in Class I. However, due to the effect of class position such an upwardly mobile person would, holding all other variables constant, only be expected to have a life satisfaction that is 0.04 points higher than that of an immobile person. ${ }^{12}$

Table 8 Own class mobility effects in Eastern Europe

\begin{tabular}{|c|c|c|c|c|}
\hline & (1) & (2) & (3) & (4) \\
\hline & $\begin{array}{l}\text { Distance travelled } \\
\text { with predetermined } \\
\text { controls }\end{array}$ & $\begin{array}{l}\text { Distance travelled } \\
\text { with full controls }\end{array}$ & $\begin{array}{l}\text { Distance travelled up } \\
\text { and down with } \\
\text { predetermined } \\
\text { controls }\end{array}$ & $\begin{array}{l}\text { Distance travelled up } \\
\text { and down with full } \\
\text { controls }\end{array}$ \\
\hline Class $=I$ & $0.740^{* * *}(0.077)$ & $0.446^{* * *}(0.095)$ & $0.739^{* * *}(0.077)$ & $0.445^{* * *}(0.095)$ \\
\hline Class $=\mathrm{II}$ & $0.318^{* * *}(0.070)$ & $0.116^{*}(0.066)$ & $0.318^{* * *}(0.071)$ & $0.115^{*}(0.066)$ \\
\hline Class=III & $0.081(0.128)$ & $-0.027(0.170)$ & $0.079(0.121)$ & $-0.030(0.163)$ \\
\hline Class $=I V$ & $-0.066(0.119)$ & $-0.061(0.146)$ & $-0.066(0.120)$ & $-0.061(0.145)$ \\
\hline Class $=\mathrm{V}$ & $-0.254^{+}(0.158)$ & $-0.139(0.168)$ & $-0.253^{+}(0.158)$ & $-0.138(0.168)$ \\
\hline Class $=\mathrm{VI}$ & $-0.491^{* * *}(0.049)$ & $-0.290^{* * *}(0.063)$ & $-0.489^{* * *}(0.050)$ & $-0.287^{* * *}(0.059)$ \\
\hline Class $=\mathrm{VII}$ & $-0.328^{* * *}(0.090)$ & $-0.045(0.066)$ & $-0.328^{* * *}(0.091)$ & $-0.044(0.066)$ \\
\hline $\mathrm{p}$ & $0.620^{* * *}(0.126)$ & $0.503^{* * *}(0.137)$ & $0.621^{* * *}(0.126)$ & $0.504^{* * *}(0.139)$ \\
\hline \#Classes moved & $0.055^{* *}(0.025)$ & $0.048^{* * *}(0.013)$ & & \\
\hline \#Classes up & & & $0.060^{* *}(0.029)$ & $0.055^{* * *}(0.018)$ \\
\hline \#Classes down & & & $-0.051+(0.033)$ & $-0.040^{+}(0.026)$ \\
\hline Fixed effects & YES & YES & YES & YES \\
\hline Predet. demographics & YES & YES & YES & YES \\
\hline Education & $\mathrm{NO}$ & YES & $\mathrm{NO}$ & YES \\
\hline More demographics & $\mathrm{NO}$ & YES & $\mathrm{NO}$ & YES \\
\hline UE \& income & $\mathrm{NO}$ & YES & $\mathrm{NO}$ & YES \\
\hline Log likelihood & -72677 & -71951 & -72677 & -71950 \\
\hline AIC & 145436 & 144008 & 145438 & 144009 \\
\hline $\mathrm{N}$ & 26620 & 26620 & 26620 & 26620 \\
\hline
\end{tabular}

$+\mathrm{p}<0.20,{ }^{*} \mathrm{p}<0.10,{ }^{* *} \mathrm{p}<0.05,{ }^{* * *} \mathrm{p}<0.01$. Region- and wave-clustered standard errors in parentheses.

${ }^{12}$ Since $(0.048 * 6)-(0.503 * 0.446-(1-0.503) *-0.045)=0.041$ 
In Columns (3) and (4), we investigate whether these effects are asymmetric with respect to upward and downward mobility. We find no evidence of loss aversion. On the contrary, the effect of upward mobility is larger than the effect of downward mobility, which in turn is even marginally insignificant. As we did for Western Europe, we check whether these results are sensitive to letting weight $p$ be conditional on class destinations or class origins (see Appendix). Our results are not significantly changed.

However, upon entering terms for reference position and reference mobility in Table 9, our estimates of the effect of own downward mobility as given in Columns (3) and (4) are now significant and slightly exceed the terms for own upward mobility. Generally, the estimates for own class mobility are nearly doubled in Table 9 compared to Table 8. Similar to what we find for Western Europe, this is driven by the positive correlation of own mobility and reference mobility. The own downward mobility term of Table 8 in particular picks up part of the reference mobility effect and is therefore biased toward zero. Because of these considerations we take our results in Table 9 as more reliable estimates for the effect of own class mobility. We therefore find corroborating evidence in favour of $\mathbf{H} \mathbf{3}$ in Eastern Europe.

Finally, we now consider the effects of reference class mobility and reference class position. As was true for Western Europe, reference mobility negatively impacts life satisfaction in all specifications, but reference position has no effects in our preferred specifications. The estimates imply that as people in the individual's reference group tend to be more upwardly mobile, the less satisfied the individual. These results disconfirm $\mathbf{H} 4 \mathbf{a}$, but corroborate $\mathbf{H} 4 \mathbf{b}$.

Note that our estimates for reference mobility exceed those for own mobility. Thus, as everybody is upwardly mobile, nobody is benefited directly from this mobility. Columns (3) and (4) show whether effects are stronger or weaker for those that were more or less mobile than those in their reference group. Contrary to Western Europe, we now find very little indication for a differential in effects suggesting that the effect of reference mobility is roughly homogenous across class 
origins. We confirm this in the Appendix. There, we also show that our main results are robust to letting parameter $p$ be conditional on class destinations or origins, and to using OLS rather than diagonal reference models.

Table 9 Reference class effects in Eastern Europe

\begin{tabular}{|c|c|c|c|c|}
\hline & (1) & (2) & (3) & (4) \\
\hline & $\begin{array}{l}\text { Distances, with } \\
\text { predetermined } \\
\text { controls }\end{array}$ & $\begin{array}{l}\text { Distances, with full } \\
\text { controls }\end{array}$ & $\begin{array}{l}\text { Distances in either } \\
\text { direction, with } \\
\text { predetermined } \\
\text { controls }\end{array}$ & $\begin{array}{l}\text { Distances in either } \\
\text { direction, with full } \\
\text { controls }\end{array}$ \\
\hline Class $=\mathrm{I}$ & $0.934^{* * *}(0.107)$ & $0.662^{* * *}(0.103)$ & $0.912^{* * *}(0.113)$ & $0.635^{* * *}(0.112)$ \\
\hline Class $=\mathrm{II}$ & $0.466^{* * *}(0.099)$ & $0.272^{* * *}(0.087)$ & $0.427^{* * *}(0.125)$ & $0.240^{* *}(0.106)$ \\
\hline Class $=$ III & $0.200^{*}(0.115)$ & $0.083(0.168)$ & $0.149^{+}(0.099)$ & $0.042(0.148)$ \\
\hline Class $=I V$ & $-0.066(0.107)$ & $-0.056(0.143)$ & $-0.091(0.123)$ & $-0.073(0.153)$ \\
\hline Class $=\mathrm{V}$ & $-0.327^{* *}(0.159)$ & $-0.220^{+}(0.169)$ & $-0.313^{*}(0.168)$ & $-0.205(0.175)$ \\
\hline Class $=\mathrm{VI}$ & $-0.633^{* * *}(0.079)$ & $-0.441^{* * *}(0.075)$ & $-0.574^{* * *}(0.108)$ & $-0.394^{* * *}(0.085)$ \\
\hline Class $=\mathrm{VII}$ & $-0.575^{* * *}(0.155)$ & $-0.301^{* * *}(0.115)$ & $-0.509^{* * *}(0.173)$ & $-0.246^{*}(0.127)$ \\
\hline $\mathrm{p}$ & $0.578^{* * *}(0.143)$ & $0.446^{* * *}(0.166)$ & $0.559^{* * *}(0.139)$ & $0.446^{* * *}(0.157)$ \\
\hline \#Classes moved & $0.117^{* * *}(0.039)$ & $0.096^{* * *}(0.032)$ & & \\
\hline Ref. class position & $-0.070^{*}(0.040)$ & $0.004(0.039)$ & & \\
\hline Ref. class mobility & $-0.144^{* * *}(0.038)$ & $-0.116^{* * *}(0.034)$ & & \\
\hline \#Classes moved up & & & $0.101^{* * *}(0.035)$ & $0.084^{* * *}(0.025)$ \\
\hline \#Classes moved down & & & $-0.126^{* * *}(0.043)$ & $-0.091^{* *}(0.042)$ \\
\hline Ref. class position (resp. is worse) & & & $-0.096^{* *}(0.043)$ & $-0.017(0.041)$ \\
\hline Ref. class position (resp. is better) & & & $-0.072^{*}(0.040)$ & $0.002(0.039)$ \\
\hline Ref. class mobility (resp. is worse) & & & $-0.167^{* * *}(0.037)$ & $-0.132^{* * *}(0.036)$ \\
\hline Ref. class mobility (resp. is better) & & & $-0.128^{* * *}(0.043)$ & $-0.107^{* * *}(0.039)$ \\
\hline Fixed effects & YES & YES & YES & YES \\
\hline Predet. demographics & YES & YES & YES & YES \\
\hline Education & $\mathrm{NO}$ & YES & $\mathrm{NO}$ & YES \\
\hline More demographics & $\mathrm{NO}$ & YES & $\mathrm{NO}$ & YES \\
\hline UE \& income & $\mathrm{NO}$ & YES & $\mathrm{NO}$ & YES \\
\hline Log likelihood & -72630 & -71912 & -72628 & -71910 \\
\hline AIC & 145347 & 143934 & 145348 & 143936 \\
\hline $\mathrm{N}$ & 26607 & 26607 & 26607 & 26607 \\
\hline
\end{tabular}

$+\mathrm{p}<0.20,{ }^{*} \mathrm{p}<0.10,{ }^{* *} \mathrm{p}<0.05,{ }^{* * *} \mathrm{p}<0.01$. Region- and wave-clustered standard errors in parentheses. 


\section{Conclusion}

We make three contributions: First, we develop a theoretical framework bringing together all the pathways through which social class may impact life satisfaction. Second, we are the first to consider how reference class position and mobility affect life satisfaction. Third, we comparatively assess the independent effects of class destination and class origin, as well as the effects of own intergenerational class mobility across two major European regions.

The ways in which social class impacts life satisfaction differ for Western Europe and Eastern Europe: First, the self-employed classes in Eastern Europe enjoy similar levels of life satisfaction as the upper salariat. This is in contrast to Western Europe, where the self-employed report levels of life satisfaction closer to the intermediate occupations and higher blue-collar workers. This pattern is likely driven by the unusual composition of the self-employed in Eastern Europe. As noted earlier, many of them are likely former members of the state-bureaucracy (Slomczyński \& Shabad, 1996) . Moreover, it appears that rapid privatisation resulted in the creation of profitable and well-integrated small-scale businesses (Gerber, 2001; Hanley, 2000) that are different from the often precarious self-employment arrangements found in Western Europe.

Second, in Eastern Europe, descendants of the upper salariat, self-employed and farmers are significantly more satisfied, even after controlling for class destination. No such pattern can be found in Western Europe, where class origin appears to play little role. This difference is likely caused by lower levels of social fluidity, i.e. a stronger association between origin and destination class net of the distribution of class origin and destination, in Eastern compared to Western Europe (Gerber \& Hout, 2004; Paskov \& Bukodi, 2018). Such a stronger association implies that parents are better able to accrue benefits to their offspring - not all of which run via class destination and are thus observable as positive life satisfaction effects of class origin.

Furthermore, we find sizable evidence of an effect of intergenerational class mobility in both Eastern and Western Europe indicating the importance of internal norms. This is in contradiction to previous studies using diagonal reference models like those of Marshall \& Firth (1999) or Zhao 
et al. (2017). Upward mobility increases and downward mobility decreases life satisfaction. That upward mobility significantly improves life satisfaction directly disconfirms Sorokin "dissociative" hypothesis. The effect of own mobility is roughly $50 \%$ larger and more robust in Eastern than in Western Europe. This is in line with our expectations: As the relative advantageousness of social classes changed over time in the East, own mobility became more salient and thus more prone to produce life satisfaction effects.

Finally, for both groups of countries we find strong and robust negative effects of reference class mobility, but no effects of reference class position. Indeed, the magnitude of the negative reference mobility effect is similar or even larger than the magnitude of the positive own class mobility effect. This suggests that although an individual's upward mobility results in an individual benefit, such mobility also produces harm by generating more demanding external norms for others. Hence, while mobility may increase an individuals satisfaction with her life, there is no societal benefit to class mobility per se.

In conclusion, social class matters greatly to life satisfaction, and it matters in more complex ways than previously considered. One's own class is not the only one that matters: It also matters in which class one was raised, whether one has been intergenerationally mobile, and where those with whom one shares a class destination originate from. 


\section{Reference}

Angrist, J., \& Pischke, J.-S. (2008). Mostly harmless econometrics. Princeton University Press.

Bernardi, F., \& Ballarino, G. (2016). Education, Occupation and Social Origin. Edward Elgar Publishing. Bessudnov, A., McKee, M., \& Stuckler, D. (2012). Inequalities in male mortality by occupational class, perceived status and education in Russia, 1994-2006. European Journal of Public Health, 22(3), 332-337.

Bihagen, E., \& Nermo, M. (2010). The effectiveness of ESeC and EGP in clustering occupations: a study of occupational wage growth in Sweden. In D. Rose \& E. Harrison (Eds.), Social Class in Europe. Routledge.

Breen, R., \& Goldthorpe, J. (1997). Explaining educational differentials: Towards a formal rational action theory. Rationality and Society, 9(3), 275-305.

Bukodi, E., \& Goldthorpe, J. (2016). Educational attainment-relative or absolute-as a mediator of intergenerational class mobility in Britain. Research in Social Stratification and Mobility, 43, 515.

Bukodi, E., \& Goldthorpe, J. (2019). Social mobility and Education in Britain: Research, Politics and Policy. Cambridge University Press.

Chan, T.-W. (2018). Social mobility and the well-being of individuals. The British Journal of Sociology, 69(1), 183-206.

Clark, A. (2003). Unemployment as a Social Norm: Psychological Evidence from Panel Data. Journal of Labor Economics, 21(2), 323-351.

Clark, A., \& D’Angelo, E. (2015). Upward Social Mobility, Well-being and Political Preferences: Evidence from the BHPS.

Clark, A., \& Senik, C. (2010). Who Compares To Whom ? the Anatomy of Income Comparisons in Europe. The Economic Journal, 120, 573-594. 
Delhey, J., \& Kohler, U. (2006). From nationally bounded to Pan-European inequalities? On the importance of foreign countries as reference groups. European Sociological Review, 22(2), 125140.

Diener, E., Inglehart, R., \& Tay, L. (2013). Theory and Validity of Life Satisfaction Scales. Social Indicators Research, 112(3), 497-527.

Diener, E., Suh, E., Lucas, R., \& Smith, H. (1999). Subjective well-being: Three decades of progress. Psychological Bulletin, 125(2), 276.

Dolan, P., \& Lordan, G. (2013). Moving Up and Sliding Down: An Empirical Assessment of the Effect of Social Mobility on Subjective Wellbeing. CEP Discussion Paper.

Drobnič, S., Beham, B., \& Präg, P. (2010). Good Job, Good Life? Working Conditions and Quality of Life in Europe. Social Indicators Research, 99(2), 205-225.

Elias, P., \& McKnight, A. (2003). Earnings, Unemployment and the NS-SEC. In D. Rose \& D. Pevalin (Eds.), A Researcher's Guide to the National Statistics Socio-economic Classification. Sage.

Erikson, R. (1984). Social Class of Men, Women and Families. Sociology, 18(4), 500-514.

Erikson, R., Goldthorpe, J., \& Portocarero, L. (1979). Intergenerational class mobility in three Western European societies: England, France and Sweden. The British Journal of Sociology, 30(4), 415-441.

Ferrer-i-Carbonell, A. (2005). Income and well-being: An empirical analysis of the comparison income effect. Journal of Public Economics, 89(5-6), 997-1019.

Ferrer-i-Carbonell, A., \& Frijters, P. (2004). How important is methodology for the estimates of the determinants of happiness? The Economic Journal, 114(497), 641-659.

Frederick, S., \& Loewenstein, G. (1999). Hedonic Adaptation. In D. Kahneman, E. Diener, \& N. Schwarz (Eds.), Well-being: Foundations of hedonic psychology.

Ganzeboom, H. (2014). ESS Developmental Project. Retrieved from http://www.harryganzeboom.nl/ESS-DEVO/index.htm

Gerber, T. P. (2001). Paths to Success. International Journal of Sociology, 31(2), 3-37. 
Gerber, T. P., \& Hout, M. (1998). More Shock than Therapy: Market Transition, Employment, and Income in Russia, 1991-1995. American Journal of Sociology, 104(1), 1-50.

Gerber, T. P., \& Hout, M. (2004). Tightening Up: Declining Class Mobility during Russia’s Market Transition. American Sociological Review, 69(5), 677-703.

Goerke, L., \& Pannenberg, M. (2015). Direct evidence for income comparisons and subjective well-being across reference groups. Economics Letters, 137, 95-101.

Goldthorpe, J., \& McKnight, A. (2006). The Economic Basis of Social Class. In D. Grusky \& P. England (Eds.), Mobility and Inequality Frontiers of Research in Sociology and Economics. Stanford University Press.

Grosfeld, I., \& Senik, C. (2010). The emerging aversion to inequality. Economics of Transition, 18(1), $1-26$.

Gugushvili, A. (2016). Intergenerational Social Mobility and Popular Explanations of Poverty: A Comparative Perspective. Social Justice Research, 29(4), 402-428.

Gugushvili, A., McKee, M., Azarova, A., Murphy, M., Irdam, D., \& King, L. (2018). Parental transmission of smoking among middle-aged and older populations in Russia and Belarus. International Journal of Public Health, 63(3), 349-358.

Hadjar, A., \& Samuel, R. (2015). Does upward social mobility increase life satisfaction? A longitudinal analysis using British and Swiss panel data. Research in Social Stratification and Mobility, 39, 48-58.

Haller, M., \& Hadler, M. (2006). How Social Relations and Structures can Produce Happiness and Unhappiness: An International Comparative Analysis. Social Indicators Research, 75(2), 169_ 216.

Hanley, E. (2000). Self-employment in post-communist Eastern Europe: a refuge from poverty or road to riches? Communist and Post-Communist Studies, 33(3), 379-402. 
Heggebø, K., \& Elstad, J. I. (2018). Is it Easier to Be Unemployed When the Experience Is More Widely Shared? Effects of Unemployment on Self-rated Health in 25 European Countries with Diverging Macroeconomic Conditions. European Sociological Review, 34(1), 22-39.

Houle, J. N. (2011). The psychological impact of intragenerational social class mobility. Social Science Research, 40(3), 757-772.

Houle, J. N., \& Martin, M. A. (2011). Does intergenerational mobility shape psychological distress? Sorokin revisited. Research in Social Stratification and Mobility, 29(2), 193-203.

Hout, M. (2004). Getting the most out of the GSS income measures.

Iveson, M. H., \& Deary, I. J. (2017). Intergenerational social mobility and subjective wellbeing in later life. Social Science \& Medicine, 188, 11-20.

Kahneman, D., \& Deaton, A. (2010). High income improves evaluation of life but not emotional well-being. PNAS, 107(38), 16489-93.

Kaiser, C. (2018). DRM: Stata module. Retrieved from https://ideas.repec.org/c/boc/bocode/s458506.html

Kelley, J., \& Zagorski, K. (2004). Economic Change and the Legitimation of Inequality: The Transition from Socialism to the Free Market in Central-East Europe. Research in Social Stratification and Mobility, 22, 319-364.

Kuitto, K. (2018). Measuring Welfare Entitlement Generosity in Transitional Welfare States: The Case of Post-communist Countries in Central and Eastern Europe. Social Indicators Research, 136(1), 203-224.

Lipps, O., \& Oesch, D. (2018). The working class left behind? The class gap in life satisfaction in Germany and Switzerland over the last decades. European Societies, 20(4), 549-571.

Lucchini, M., \& Schizzerotto, A. (2010). Unemployment risks in four EU countries: a validation study of the ESeC. In D. Rose \& E. Harrison (Eds.), Social Class in Europe An Introduction to the European Socio-economic Classification. Routledge. 
Luechinger, S., Meier, S., \& Stutzer, A. (2010). Why Does Unemployment Hurt the Employed? Evidence from the Life Satisfaction Gap Between the Public and the Private Sector. Journal of Human Resources, 45(4), 998-1045.

Marshall, G., \& Firth, D. (1999). Social mobility and personal satisfaction: evidence from ten countries*. The British Journal of Sociology, 50(1), 28-48.

McBride, M. (2001). Relative-income effects on subjective well-being in the cross-section. Journal of Economic Behavior \& Organization, 45(3), 251-278.

Melchior, M., Krieger, N., Kawachi, I., Berkman, L. F., Niedhammer, I., \& Goldberg, M. (2005). Work Factors and Occupational Class Disparities in Sickness Absence: Findings From the GAZEL Cohort Study. American Journal of Public Health, 95(7), 1206-1212.

Michalos, A. C. (1985). Multiple Discrepancies Theory (MDT). Social Indicators Research, 16(4), 347413.

Newman, K. S. (1999). Falling from grace: Downward mobility in the age of affluence. Univ of California Press.

Nikolaev, B., \& Burns, A. (2014). Intergenerational mobility and subjective well-being-Evidence from the general social survey. Journal of Behavioral and Experimental Economics, 53, 82-96.

Nolan, B., \& Whelan, C. T. (2011). Poverty and deprivation in Europe. OUP Catalogue.

Paskov, M., \& Bukodi, E. (2018). Income inequality, living standards and intergenerational social mobility. In B. Nolan (Ed.), Generating Prosperity for Working Families in Affluent Countries. Oxford University Press.

Paugam, S., \& Zhou, Y. (2009). Job Insecurity. In D. Gallie (Ed.), Employment Regimes and the Quality of Work. Oxford University Press.

Pavot, W., \& Diener, E. (2008). The Satisfaction With Life Scale and the emerging construct of life satisfaction. The Journal of Positive Psychology, 3(2), 137-152. 
Pichler, F., \& Wallace, C. (2009). What are the Reasons for Differences in Job Satisfaction across Europe? Individual, Compositional, and Institutional Explanations. European Sociological Review, 25(5), 535-549.

Riedl, M., \& Geishecker, I. (2014). Keep it simple: estimation strategies for ordered response models with fixed effects. Journal of Applied Statistics, 41(11), 2358-2374.

Rose, D., Harrison, E., \& Pevalin, D. J. (2009). The European socio-economic classification: A prolegomenon.

Schuck, B., \& Steiber, N. (2017). Does Intergenerational Educational Mobility Shape the WellBeing of Young Europeans? Evidence from the European Social Survey. Social Indicators Research.

Senik, C. (2009). Direct evidence on income comparisons and their welfare effects. Journal of Economic Behavior and Organization, 72(1), 408-424.

Shavit, Y., \& Blossfeld, H.-P. (1993). Persistent Inequality. Westview Press.

Slomczyński, K. M., \& Shabad, G. (1996). Systemic transformation and the salience of class structure in East Central Europe. East European Politics and Societies, 11(1), 155-189.

Sobel, M. E. (1981). Diagonal Mobility Models: A Substantively Motivated Class of Designs for the Analysis of Mobility Effects. American Sociological Review, 46(6), 893.

Solt, F. (2019). Measuring Income Inequality Across Countries and Over Time: The Standardized World Income Inequality Database. SWIID Version 8.0.

Sorokin, P. A. (1959). Social and cultural mobility. The Free Press.

Vågerö, D. (2010). The East-West Health Divide in Europe: Growing and Shifting Eastwards. European Review, 18(1), 23-34.

van der Waal, J., Daenekindt, S., \& de Koster, W. (2017). Statistical challenges in modelling the health consequences of social mobility: the need for diagonal reference models. International Journal of Public Health, 62(9), 1029-1037. 
Vendrik, M. C. M. (2013). Adaptation, anticipation and social interaction in happiness: An integrated error-correction approach. Journal of Public Economics, 105, 131-149.

Vendrik, M. C. M., \& Woltjer, G. B. (2007). Happiness and loss aversion: Is utility concave or convex in relative income? Journal of Public Economics, 91(7-8), 1423-1448.

Warren, T. (2015). Work-time underemployment and financial hardship: class inequalities and recession in the UK. Work, Employment and Society, 29(2), 191-212.

White, C., Glickman, M., Johnson, B., \& Corbin, T. (2007). Social inequalities in adult male mortality by the National Statistics Socio-Economic Classification, England and Wales, 2001-03. Health Statistics Quarterly, (36), 6-23.

Wolbring, T., Keuschnigg, M., \& Negele, E. (2013). Needs, Comparisons, and Adaptation: The Importance of Relative Income for Life Satisfaction. European Sociological Review, 29(1), 86104.

Wulfgramm, M. (2014). Life satisfaction effects of unemployment in Europe: The moderating influence of labour market policy. Journal of European Social Policy, (3), 258-272.

Zang, E., \& de Graaf, N. D. (2016). Frustrated Achievers or Satisfied Losers? Inter- and Intragenerational Social Mobility and Happiness in China. Sociological Science, 3, 779-800.

Zhao, Y., Li, Y., Heath, A., \& Shryane, N. (2017). Inter- and intra-generational social mobility effects on subjective well-being - Evidence from mainland China. Research in Social Stratification and Mobility, 48, 54-66. 


\section{Appendix / Supplementary Material}

Table D1 List of countries and observed years

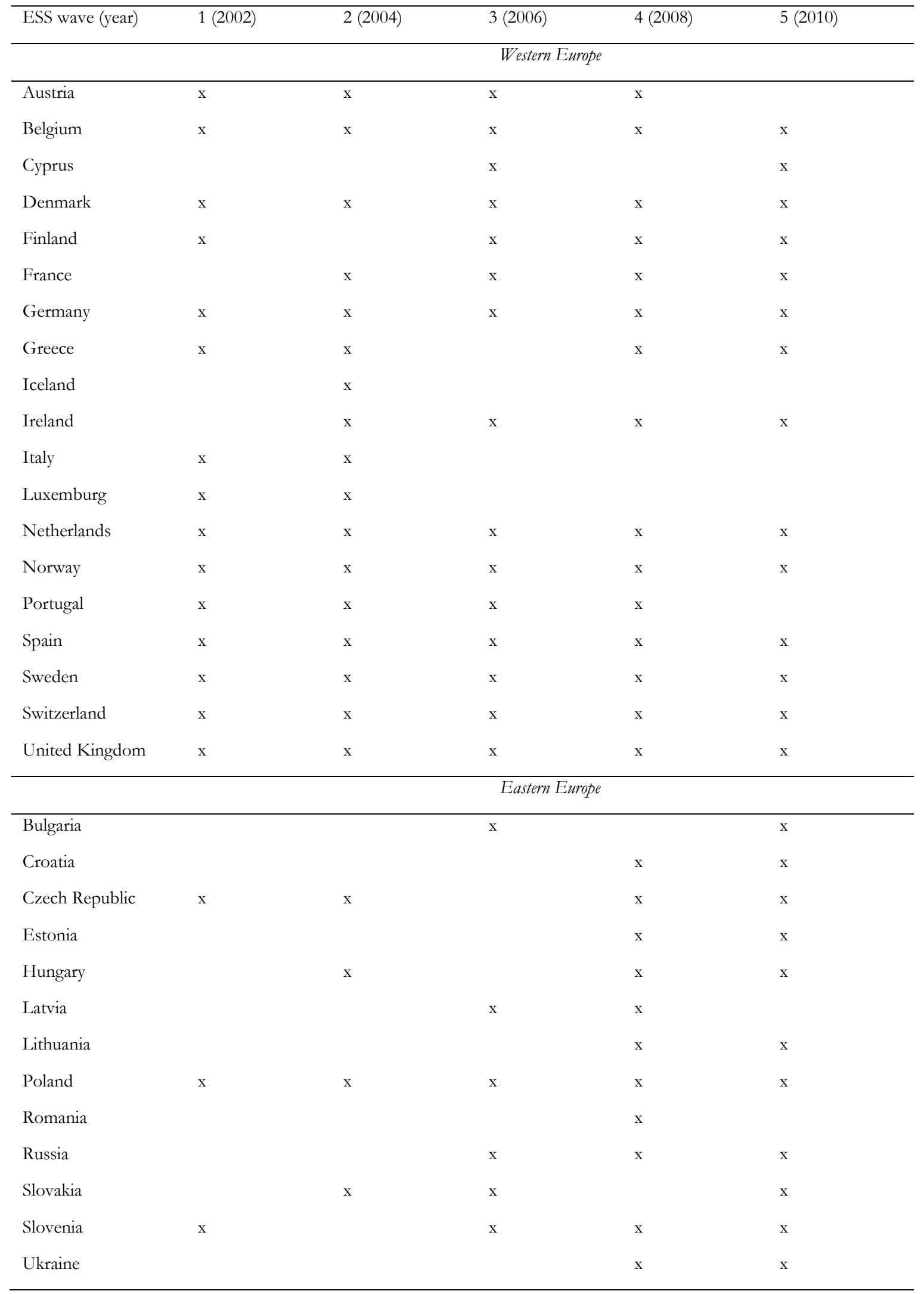


Table D2 Number of observations and shares of class origin and destination combinations

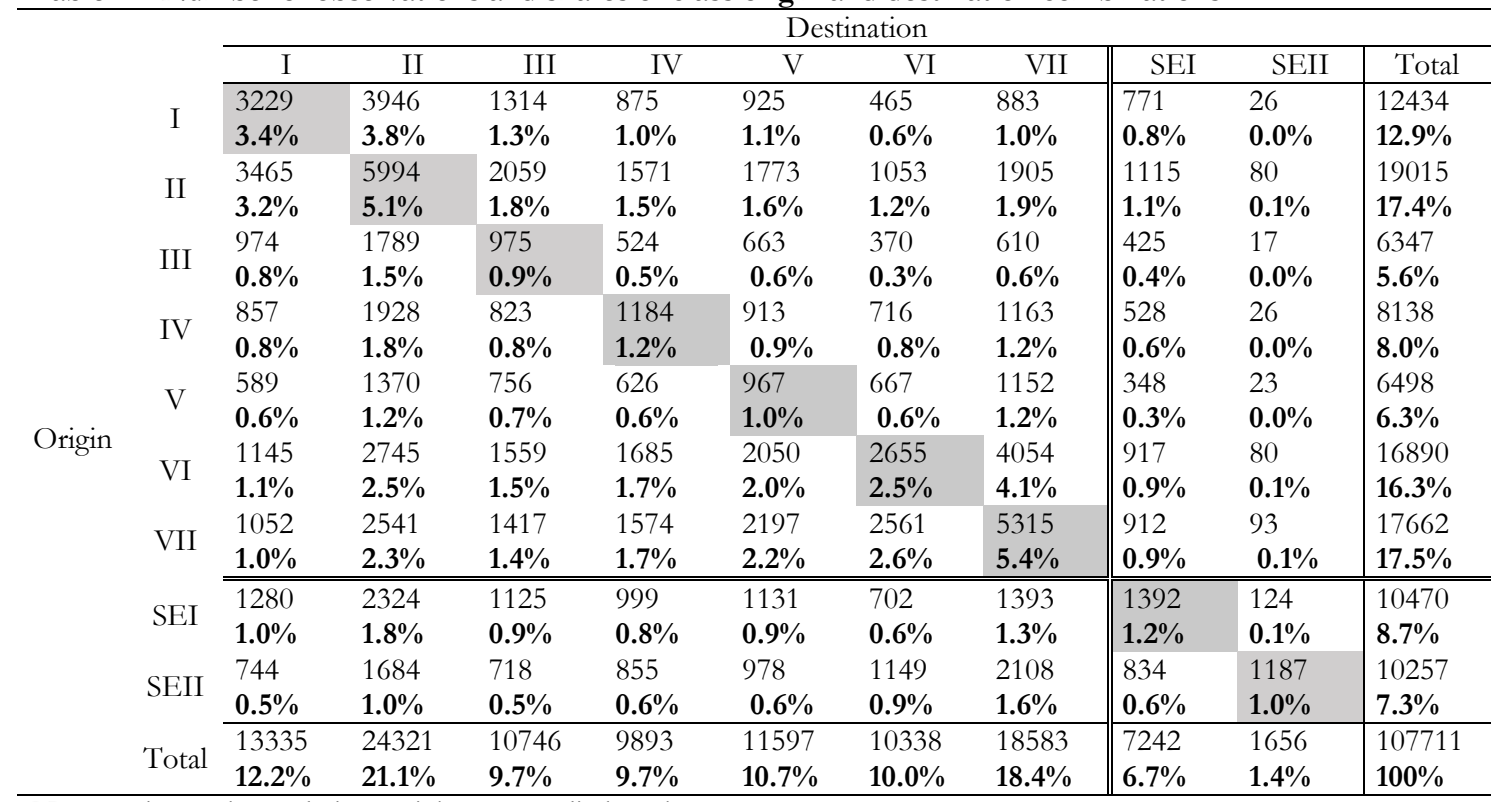

Note: Design and population weights are applied to shares.

Table D3 Number of observations and shares of class origin and destination combinations, Western Europe

\begin{tabular}{|c|c|c|c|c|c|c|c|c|c|c|c|}
\hline \multirow{22}{*}{ Origin } & & & & & & Des & ation & & & & \\
\hline & & $\mathrm{I}$ & II & III & IV & $\mathrm{V}$ & VI & VII & SEI & SEII & Total \\
\hline & \multirow{2}{*}{ I } & 2428 & 2897 & 976 & 635 & 625 & 235 & 481 & 556 & 19 & 8852 \\
\hline & & $3.1 \%$ & $3.6 \%$ & $1.3 \%$ & $0.9 \%$ & $0.8 \%$ & $0.3 \%$ & $0.7 \%$ & $0.9 \%$ & $0.0 \%$ & $11.6 \%$ \\
\hline & \multirow{2}{*}{ II } & 2667 & 4602 & 1580 & 1202 & 1250 & 531 & 1120 & 851 & 63 & 13866 \\
\hline & & $3.3 \%$ & $5.4 \%$ & $2.0 \%$ & $1.7 \%$ & $1.5 \%$ & $0.7 \%$ & $1.6 \%$ & $1.2 \%$ & $0.1 \%$ & $17.5 \%$ \\
\hline & \multirow{2}{*}{ III } & 810 & 1456 & 809 & 436 & 532 & 241 & 435 & 344 & 15 & 5078 \\
\hline & & $1.1 \%$ & $1.9 \%$ & $1.2 \%$ & $0.6 \%$ & $0.7 \%$ & $0.4 \%$ & $0.7 \%$ & $0.5 \%$ & $0.0 \%$ & $7.1 \%$ \\
\hline & \multirow{2}{*}{ IV } & 628 & 1511 & 676 & 909 & 714 & 413 & 790 & 422 & 15 & 6078 \\
\hline & & $0.9 \%$ & $2.1 \%$ & $1.0 \%$ & $1.4 \%$ & $1.0 \%$ & $0.7 \%$ & $1.2 \%$ & $0.7 \%$ & $0.0 \%$ & $9.0 \%$ \\
\hline & \multirow{2}{*}{$\mathrm{V}$} & 423 & 983 & 567 & 479 & 666 & 353 & 656 & 251 & 17 & 4395 \\
\hline & & $0.5 \%$ & $1.2 \%$ & $0.8 \%$ & $0.6 \%$ & $0.9 \%$ & $0.4 \%$ & $1.0 \%$ & $0.3 \%$ & $0.0 \%$ & $5.8 \%$ \\
\hline & \multirow{2}{*}{ VI } & 726 & 1763 & 1076 & 1207 & 1276 & 1345 & 2131 & 635 & 50 & 10209 \\
\hline & & $0.9 \%$ & $2.4 \%$ & $1.5 \%$ & $1.9 \%$ & $1.8 \%$ & $1.9 \%$ & $3.5 \%$ & $0.9 \%$ & $0.1 \%$ & $15.1 \%$ \\
\hline & \multirow{2}{*}{ VII } & 657 & 1605 & 979 & 1106 & 1397 & 1219 & 2803 & 684 & 50 & 10500 \\
\hline & & $0.8 \%$ & $2.0 \%$ & $1.3 \%$ & $1.6 \%$ & $1.8 \%$ & $1.6 \%$ & $4.3 \%$ & $1.0 \%$ & $0.1 \%$ & $14.6 \%$ \\
\hline & \multirow{2}{*}{ SEI } & 1179 & 2158 & 1054 & 925 & 1048 & 584 & 1228 & 1326 & 119 & 9621 \\
\hline & & $1.4 \%$ & $2.4 \%$ & $1.3 \%$ & $1.1 \%$ & $1.3 \%$ & $0.7 \%$ & $1.7 \%$ & $1.7 \%$ & $0.2 \%$ & $12.0 \%$ \\
\hline & \multirow{3}{*}{ SEII } & 638 & 1466 & 616 & 732 & 821 & 850 & 1563 & 760 & 920 & 8366 \\
\hline & & $0.5 \%$ & $1.1 \%$ & $0.5 \%$ & $0.7 \%$ & $0.6 \%$ & $0.8 \%$ & $1.5 \%$ & $0.8 \%$ & $0.8 \%$ & $7.3 \%$ \\
\hline & & 10156 & 18441 & 8333 & 5771 & 11207 & 7631 & 8329 & 5829 & 1268 & 76965 \\
\hline & Total & $12.5 \%$ & $22.2 \%$ & $11.0 \%$ & $7.6 \%$ & $16.2 \%$ & $10.7 \%$ & $10.5 \%$ & $8.1 \%$ & $1.2 \%$ & $100 \%$ \\
\hline
\end{tabular}

Note: Design and population weights are applied to shares. 
Table D4 Number of observations and shares of class origin and destination combinations, Eastern Europe

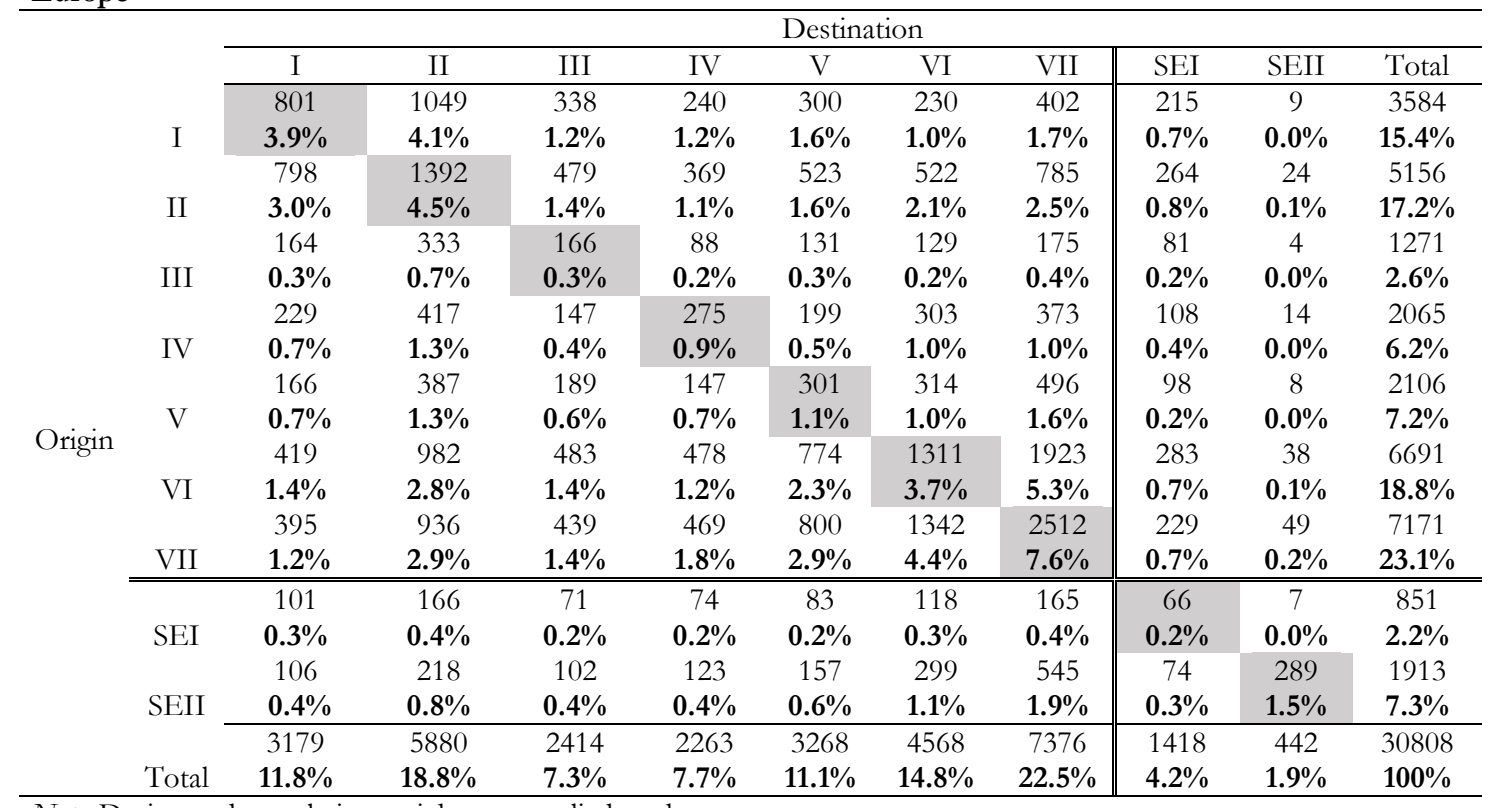

Note: Design and population weights are applied to shares. 
Table D5 Variable descriptions

\begin{tabular}{|c|c|c|c|}
\hline Treated continously & Mean & SD & Min-Max \\
\hline Life satisfaction & 6.50 & 2.39 & $0-10$ \\
\hline Own mobility & 0.22 & 2.49 & $-6-6$ \\
\hline Reference position & 3.94 & 0.92 & $1-7$ \\
\hline Reference mobility & 0.20 & 1.49 & $-5.02-5.25$ \\
\hline Age & 45.94 & 12.28 & $25-74$ \\
\hline Age squared & $2,260.81$ & $1,154.84$ & $625-5,476$ \\
\hline Years of education & 12.96 & 3.74 & $0-56$ \\
\hline Years of education squared & 181.93 & 104.80 & $0-3,136$ \\
\hline Household size & 2.94 & 1.36 & $1-15$ \\
\hline Household size squared & 10.48 & 10.19 & $1-225$ \\
\hline Ln real HH income & 10.58 & 1.42 & $6.15-18.56$ \\
\hline Treated categorically & Category & $\mathrm{N}$ & Share $(\%)$ \\
\hline \multirow[t]{2}{*}{ Unemployed } & No & 100,918 & 93.72 \\
\hline & Yes & 6,855 & 6.28 \\
\hline \multirow[t]{2}{*}{ Gender } & Female & 51,820 & 49.32 \\
\hline & Male & 55,953 & 50.68 \\
\hline \multirow[t]{2}{*}{ Ethnic minority } & No & 102,557 & 93.25 \\
\hline & Yes & 5,216 & 6.75 \\
\hline \multirow[t]{2}{*}{ Born in country } & No & 98678 & 91.65 \\
\hline & Yes & 9095 & 8.35 \\
\hline \multirow[t]{2}{*}{ Religious } & No & 44,584 & 41.51 \\
\hline & Yes & 63,189 & 58.49 \\
\hline \multirow[t]{3}{*}{ Married/Partnered } & No & 40,481 & 33.94 \\
\hline & Yes & 64,789 & 65.36 \\
\hline & NA/No answer & 2,503 & 0.70 \\
\hline \multirow[t]{4}{*}{ Place of domicile } & Big city & 21,415 & 21.03 \\
\hline & Suburbs & 13,470 & 11.38 \\
\hline & Town & 33,336 & 34.70 \\
\hline & Country/Village & 39,552 & 32.88 \\
\hline \multirow[t]{5}{*}{ ESS round } & 2002 & 16,208 & 13.16 \\
\hline & 2004 & 18,868 & 15.57 \\
\hline & 2006 & 20,154 & 20.77 \\
\hline & 2008 & 26,241 & 25.09 \\
\hline & 2010 & 26,302 & 25.40 \\
\hline NUTS I Region & 102 Separate regic & & \\
\hline
\end{tabular}

Note: Overall N is 107,711. Mean, SD and shares are computed using population and design weights. Ns are unweighted. ESeC destination and origin class are described in Tables D2-D4. 
Table A1 Own class mobility effects in Western Europe, weights conditional on class destination

(1) with predetermined controls
Distance travelled
(2)

Distance travelled with full controls
(3)

Distance travelled up and down with predetermined controls

\begin{tabular}{|c|c|c|c|c|}
\hline Class $=I$ & $0.528^{* * *}(0.044)$ & $0.214^{* * *}(0.048)$ & $0.513^{* * *}(0.047)$ & $0.202^{* * *}(0.046)$ \\
\hline Class $=\mathrm{II}$ & $0.369^{* * *}(0.041)$ & $0.208^{* * *}(0.043)$ & $0.357^{* * *}(0.044)$ & $0.186^{* * *}(0.045)$ \\
\hline Class $=$ III & $0.197^{* * *}(0.039)$ & $0.119^{* * *}(0.035)$ & $0.200^{* * *}(0.044)$ & $0.121^{* * *}(0.036)$ \\
\hline Class $=I V$ & $-0.116^{*}(0.063)$ & $-0.131^{*}(0.079)$ & $-0.098^{+}(0.074)$ & $-0.128^{+}(0.083)$ \\
\hline Class $=\mathrm{V}$ & $-0.253^{* * *}(0.091)$ & $-0.141^{+}(0.108)$ & $-0.245^{* *}(0.118)$ & $-0.112(0.107)$ \\
\hline Class $=\mathrm{VI}$ & $-0.268^{* * *}(0.062)$ & $-0.069(0.068)$ & $-0.225^{* * *}(0.079)$ & $-0.031(0.058)$ \\
\hline Class $=$ VII & $-0.459^{* * *}(0.047)$ & $-0.201^{* * *}(0.069)$ & $-0.501^{* * *}(0.091)$ & $-0.239^{* * *}(0.075)$ \\
\hline pI & $0.806^{* * *}(0.118)$ & $0.742^{* * *}(0.238)$ & $0.802^{* * *}(0.270)$ & $0.951^{* * *}(0.291)$ \\
\hline pII & $0.741^{* * *}(0.124)$ & $0.962^{* * *}(0.263)$ & $0.719^{* * *}(0.127)$ & $0.678^{* *}(0.287)$ \\
\hline pIII & $0.929^{* * *}(0.121)$ & 1.000 (constr.) & $0.747^{* * *}(0.130)$ & 1.000 (constr.) \\
\hline pIV & $0.658^{* * *}(0.141)$ & $0.398^{+}(0.298)$ & $0.467^{* *}(0.212)$ & $0.180(0.374)$ \\
\hline pv & $0.649^{* * *}(0.162)$ & $0.476^{+}(0.296)$ & $0.420^{* * *}(0.217)$ & $0.265(0.378)$ \\
\hline pVI & 1.000 (constr.) & 1.000 (constr.) & $0.695^{* *}(0.294)$ & $0.743^{+}(0.557)$ \\
\hline pVII & 1.000 (constr.) & $0.998^{* *}(0.456)$ & $0.641^{* *}(0.301)$ & $0.530(0.461)$ \\
\hline \#Classes moved & $0.017(0.014)$ & $0.020^{+}(0.014)$ & & \\
\hline \#Classes up & & & $0.015(0.041)$ & $0.001(0.017)$ \\
\hline \#Classes down & & & $-0.075(0.064)$ & $-0.057^{* *}(0.026)$ \\
\hline Fixed effects & YES & YES & YES & YES \\
\hline Predet. demogr. & YES & YES & YES & YES \\
\hline Education & $\mathrm{NO}$ & YES & $\mathrm{NO}$ & YES \\
\hline More demogr. & $\mathrm{NO}$ & YES & $\mathrm{NO}$ & YES \\
\hline UE \& income & $\mathrm{NO}$ & YES & $\mathrm{NO}$ & YES \\
\hline Log likelihood & -114122 & -112150 & -114119 & -112145 \\
\hline AIC & 228436 & 224516 & 228437 & 224511 \\
\hline $\mathrm{N}$ & 55006 & 55006 & 55006 & 55006 \\
\hline
\end{tabular}

(4)

Distance travelled up and down with full controls 
$\underline{\text { Table A2 Origin-specific effects of reference mobility }}$

\begin{tabular}{|c|c|c|c|c|}
\hline & (1) & (2) & (3) & (4) \\
\hline & $\begin{array}{l}\text { Western Europe } \\
\text { with predetermined } \\
\text { controls }\end{array}$ & $\begin{array}{l}\text { Western Europe } \\
\text { with full controls }\end{array}$ & $\begin{array}{c}\text { Eastern Europe } \\
\text { with predetermined } \\
\text { controls }\end{array}$ & $\begin{array}{l}\text { Western Europe } \\
\text { with full controls }\end{array}$ \\
\hline Class $=\mathrm{I}$ & $0.552^{* * *}(0.077)$ & $0.313^{* * *}(0.074)$ & $0.922^{* * *}(0.097)$ & $0.654^{* * *}(0.105)$ \\
\hline Class $=\mathrm{II}$ & $0.384^{* * *}(0.063)$ & $0.258^{* * *}(0.059)$ & $0.479^{* * *}(0.094)$ & $0.282^{* * *}(0.083)$ \\
\hline Class $=$ III & $0.237^{* * *}(0.089)$ & $0.206^{* * *}(0.057)$ & $0.204^{*}(0.110)$ & $0.085(0.173)$ \\
\hline Class $=\mathrm{IV}$ & $-0.072(0.058)$ & $-0.061(0.062)$ & $-0.068(0.111)$ & $-0.063(0.152)$ \\
\hline Class $=\mathrm{V}$ & $-0.215^{* * *}(0.069)$ & $-0.147^{* *}(0.065)$ & $-0.324^{* *}(0.156)$ & $-0.218^{+}(0.168)$ \\
\hline Class $=\mathrm{VI}$ & $-0.292^{* *}(0.126)$ & $-0.159^{+}(0.110)$ & $-0.633^{* * *}(0.080)$ & $-0.435^{* * *}(0.076)$ \\
\hline Class $=\mathrm{VII}$ & $-0.594^{* * *}(0.109)$ & $-0.410^{* * *}(0.090)$ & $-0.580^{* * *}(0.155)$ & $-0.305^{* * *}(0.115)$ \\
\hline $\mathrm{p}$ & $0.692(0.609)$ & $0.712^{*}(0.367)$ & $0.600^{* * *}(0.133)$ & $0.463^{* * *}(0.177)$ \\
\hline \#Classes moved & $0.063(0.117)$ & $0.041(0.046)$ & $0.111^{* * *}(0.037)$ & $0.093^{* * *}(0.033)$ \\
\hline Ref. class position & $-0.046^{+}(0.033)$ & $-0.013(0.032)$ & $-0.069^{*}(0.039)$ & $0.004(0.039)$ \\
\hline Ref. class mobility (Orig. $=\mathrm{I}$ ) & $-0.028(0.040)$ & $-0.058^{+}(0.039)$ & $-0.124^{* * *}(0.039)$ & $-0.105^{* * *}(0.039)$ \\
\hline Ref. class mobility (Orig. $=\mathrm{II})$ & $-0.037(0.036)$ & $-0.064^{*}(0.033)$ & $-0.174^{* * *}(0.038)$ & $-0.143^{* * *}(0.040)$ \\
\hline Ref. class mobility (Orig. $=\mathrm{III})$ & $0.000(0.040)$ & $-0.034(0.038)$ & $-0.135^{* *}(0.068)$ & $-0.116^{+}(0.077)$ \\
\hline Ref. class mobility (Orig. $=$ IV) & $-0.062^{+}(0.042)$ & $-0.081^{*}(0.042)$ & $-0.123^{* *}(0.058)$ & $-0.088^{+}(0.060)$ \\
\hline Ref. class mobility (Orig. $=\mathrm{V}$ ) & $-0.065(0.051)$ & $-0.098^{* *}(0.048)$ & $-0.146^{* *}(0.064)$ & $-0.120^{* *}(0.057)$ \\
\hline Ref. class mobility (Orig. $=\mathrm{VI})$ & $-0.085^{* *}(0.036)$ & $-0.106^{* * *}(0.035)$ & $-0.131^{* * *}(0.046)$ & $-0.089^{* *}(0.043)$ \\
\hline Ref. class mobility (Orig. $=\mathrm{VII})$ & $-0.072^{+}(0.046)$ & $-0.107^{* *}(0.043)$ & $-0.152^{* * *}(0.054)$ & $-0.131^{* * *}(0.048)$ \\
\hline Fixed effects & YES & YES & YES & YES \\
\hline Predet. demogr. & YES & YES & YES & YES \\
\hline Education & $\mathrm{NO}$ & YES & $\mathrm{NO}$ & YES \\
\hline More demogr. & $\mathrm{NO}$ & YES & $\mathrm{NO}$ & YES \\
\hline UE \& income & $\mathrm{NO}$ & YES & $\mathrm{NO}$ & YES \\
\hline Log likelihood & -114087 & -112114 & -72628 & -71909 \\
\hline AIC & 228375 & 224453 & 145354 & 143940 \\
\hline $\mathrm{N}$ & 54990 & 54990 & 26607 & 26607 \\
\hline
\end{tabular}

$+\mathrm{p}<0.20,{ }^{*} \mathrm{p}<0.10,{ }^{* *} \mathrm{p}<0.05,{ }^{* * *} \mathrm{p}<0.01$. Region- and wave-clustered standard errors in parentheses. 
Table A3 Reference class effects in Western Europe, weights conditional on class destination

(1)

Distances, with predetermined controls
(2) controls
Distances, with full

(3)

Distances in either direction, with predetermined controls

\begin{tabular}{|c|c|c|c|c|}
\hline & & & & \\
\hline Class $=\mathrm{I}$ & $0.563^{* * *}(0.081)$ & $0.329^{* * *}(0.079)$ & $0.464^{* * *}(0.102)$ & $0.240^{* * *}(0.070)$ \\
\hline Class $=\mathrm{II}$ & $0.399^{* * *}(0.057)$ & $0.292^{* * *}(0.057)$ & $0.340^{* * *}(0.081)$ & $0.219^{* * *}(0.071)$ \\
\hline Class $=\mathrm{III}$ & $0.215^{* * *}(0.047)$ & $0.171^{* * *}(0.046)$ & $0.199^{* * *}(0.059)$ & $0.144^{* * *}(0.052)$ \\
\hline Class $=I V$ & $-0.101+(0.062)$ & $-0.104^{+}(0.074)$ & $-0.046(0.080)$ & $-0.076(0.091)$ \\
\hline Class $=\mathrm{V}$ & $-0.272^{* * *}(0.093)$ & $-0.191^{* *}(0.095)$ & $-0.220^{*}(0.120)$ & $-0.116(0.113)$ \\
\hline Class $=\mathrm{VI}$ & $-0.293^{* * *}(0.078)$ & $-0.149^{*}(0.082)$ & $-0.198^{*}(0.110)$ & $-0.065(0.077)$ \\
\hline Class $=$ VII & $-0.512^{* * *}(0.082)$ & $-0.348^{* * *}(0.088)$ & $-0.540^{* * *}(0.108)$ & $-0.346^{* * *}(0.087)$ \\
\hline pI & $0.817^{* * *}(0.114)$ & $0.745^{* * *}(0.207)$ & $0.929^{* * *}(0.293)$ & 1.000 (constr.) \\
\hline pII & $0.749^{* * *}(0.116)$ & $0.584^{* * *}(0.175)$ & $0.790^{* * *}(0.150)$ & $0.736^{* * *}(0.176)$ \\
\hline PIII & $0.923^{* * *}(0.113)$ & $0.889^{* * *}(0.184)$ & $0.887^{* * *}(0.159)$ & $0.972^{* * *}(0.206)$ \\
\hline pIV & $0.681^{* * *}(0.132)$ & $0.475^{* *}(0.204)$ & $0.443^{+}(0.298)$ & $0.186(0.361)$ \\
\hline pv & $0.666^{* * *}(0.150)$ & $0.564^{* * *}(0.201)$ & $0.413^{+}(0.295)$ & $0.346^{+}(0.267)$ \\
\hline PVI & $0.997^{* * *}(0.166)$ & 1.000 (constr.) & $0.694^{* *}(0.294)$ & $0.769^{* *}(0.319)$ \\
\hline pVII & 1.000 (constr.) & $0.942^{* * *}(0.233)$ & $0.605^{* *}(0.283)$ & $0.600^{* *}(0.242)$ \\
\hline \#Classes moved & $0.036^{*}(0.021)$ & $0.039^{*}(0.023)$ & & \\
\hline Ref. class position & $-0.051+(0.032)$ & $-0.019(0.031)$ & & \\
\hline Ref. class mobility & $-0.053^{+}(0.033)$ & $-0.084^{* * *}(0.032)$ & & \\
\hline \#Classes moved up & & & $0.045(0.043)$ & $0.035^{+}(0.021)$ \\
\hline \#Classes moved down & & & $-0.076^{*}(0.043)$ & $-0.052^{*}(0.028)$ \\
\hline Ref. class position (resp. is worse) & & & $-0.068^{*}(0.041)$ & $-0.037(0.036)$ \\
\hline Ref. class position (resp. is better) & & & $-0.054^{+}(0.033)$ & $-0.020(0.032)$ \\
\hline Ref. class mobility (resp. is worse) & & & $-0.008(0.039)$ & $-0.038(0.034)$ \\
\hline Ref. class mobility (resp. is better) & & & $-0.083^{* *}(0.038)$ & $-0.110^{* * *}(0.037)$ \\
\hline Fixed effects & YES & YES & YES & YES \\
\hline Predet. demographics & YES & YES & YES & YES \\
\hline Education & $\mathrm{NO}$ & YES & NO & YES \\
\hline More demographics & $\mathrm{NO}$ & YES & $\mathrm{NO}$ & YES \\
\hline Unemployment \& income & $\mathrm{NO}$ & YES & $\mathrm{NO}$ & YES \\
\hline Log likelihood & -114082 & -112108 & -114073 & -112097 \\
\hline AIC & 228363 & 224438 & 228352 & 224422 \\
\hline $\mathrm{N}$ & 54990 & 54990 & 54990 & 54990 \\
\hline
\end{tabular}

(4)

Distances in either direction, with full controls

$+\mathrm{p}<0.20,{ }^{*} \mathrm{p}<0.10,{ }^{* *} \mathrm{p}<0.05,{ }^{* * *} \mathrm{p}<0.01$. Region- and wave-clustered standard errors in parentheses. 
$\underline{\text { Table A4 Reference class effects in Western Europe, weights conditional on class origin }}$

\begin{tabular}{|c|c|c|c|c|}
\hline & (1) & (2) & (3) & (4) \\
\hline & $\begin{array}{l}\text { Distances, with } \\
\text { predetermined } \\
\text { controls }\end{array}$ & $\begin{array}{l}\text { Distances, with full } \\
\text { controls }\end{array}$ & $\begin{array}{l}\text { Distances in either } \\
\text { direction, with } \\
\text { predetermined } \\
\text { controls }\end{array}$ & $\begin{array}{l}\text { Distances in either } \\
\text { direction, with full } \\
\text { controls }\end{array}$ \\
\hline Class $=\mathrm{I}$ & $0.556^{* * *}(0.082)$ & $0.305^{* * *}(0.072)$ & $0.546^{* * *}(0.084)$ & $0.294^{* * *}(0.094)$ \\
\hline Class $=\mathrm{II}$ & $0.380^{* * *}(0.062)$ & $0.245^{* * *}(0.059)$ & $0.375^{* * *}(0.068)$ & $0.224^{* *}(0.098)$ \\
\hline Class $=$ III & $0.252^{* * *}(0.062)$ & $0.236^{* * *}(0.057)$ & $0.257^{* * *}(0.063)$ & $0.239^{* * *}(0.061)$ \\
\hline Class $=I V$ & $-0.086^{+}(0.061)$ & $-0.082^{+}(0.060)$ & $-0.063(0.069)$ & $-0.064(0.076)$ \\
\hline Class $=\mathrm{V}$ & $-0.235^{* * *}(0.085)$ & $-0.167^{* *}(0.084)$ & $-0.234^{* *}(0.094)$ & $-0.189^{+}(0.127)$ \\
\hline Class $=\mathrm{VI}$ & $-0.268^{* * *}(0.082)$ & $-0.138^{*}(0.079)$ & $-0.274^{* * *}(0.101)$ & $-0.120(0.138)$ \\
\hline Class $=$ VII & $-0.600^{* * *}(0.093)$ & $-0.398^{* * *}(0.083)$ & $-0.606^{* * *}(0.101)$ & $-0.385^{* * *}(0.140)$ \\
\hline pI & $0.640^{* *}(0.250)$ & $0.604^{* *}(0.248)$ & $0.658^{* *}(0.380)$ & $0.419(0.538)$ \\
\hline pII & $0.639^{* * *}(0.125)$ & $0.652^{* * *}(0.198)$ & $0.631^{* * *}(0.128)$ & $0.445^{* *}(0.214)$ \\
\hline PIII & $0.858^{* * *}(0.187)$ & $1.000^{* * *}(0.248)$ & $0.857^{* * *}(0.190)$ & $0.869^{*}(0.448)$ \\
\hline pIV & $0.552^{* * *}(0.147)$ & $0.618^{* *}(0.259)$ & $0.597^{* * *}(0.181)$ & $0.646^{+}(0.481)$ \\
\hline pv & $0.612^{* * *}(0.168)$ & $0.618^{* *}(0.300)$ & $0.539^{* *}(0.250)$ & $0.750(0.686)$ \\
\hline pVI & $0.455^{* * *}(0.143)$ & $0.425^{* *}(0.214)$ & $0.534^{* * *}(0.199)$ & $0.530(0.424)$ \\
\hline pVII & $0.554^{* * *}(0.117)$ & $0.527^{* *}(0.212)$ & $0.587^{* * *}(0.203)$ & $0.580(0.509)$ \\
\hline \#Classes moved & $0.081^{*}(0.047)$ & $0.055^{* * *}(0.021)$ & & \\
\hline Ref. class position & $-0.054^{+}(0.033)$ & $-0.023(0.032)$ & & \\
\hline Ref. class mobility & $-0.055^{*}(0.032)$ & $-0.080^{* *}(0.031)$ & & \\
\hline \#Classes moved up & & & $0.090^{+}(0.059)$ & $0.059^{* *}(0.029)$ \\
\hline \#Classes moved down & & & $-0.063(0.076)$ & $-0.062(0.053)$ \\
\hline Ref. class position (resp. is worse) & & & $-0.048^{+}(0.036)$ & $-0.020(0.040)$ \\
\hline Ref. class position (resp. is better) & & & $-0.049^{+}(0.033)$ & $-0.020(0.037)$ \\
\hline Ref. class mobility (resp. is worse) & & & $-0.024(0.035)$ & $-0.046(0.038)$ \\
\hline Ref. class mobility (resp. is better) & & & $-0.085^{* *}(0.040)$ & $-0.107^{* *}(0.045)$ \\
\hline Fixed effects & YES & YES & YES & YES \\
\hline Predet. demographics & YES & YES & YES & YES \\
\hline Education & $\mathrm{NO}$ & YES & NO & YES \\
\hline More demographics & $\mathrm{NO}$ & YES & $\mathrm{NO}$ & YES \\
\hline Unemployment \& income & $\mathrm{NO}$ & YES & $\mathrm{NO}$ & YES \\
\hline Log likelihood & -114086 & -112112 & -114081 & -112105 \\
\hline AIC & 228372 & 224447 & 228369 & 224441 \\
\hline $\mathrm{N}$ & 54990 & 54990 & 54990 & 54990 \\
\hline
\end{tabular}

$+\mathrm{p}<0.20,{ }^{*} \mathrm{p}<0.10,{ }^{* *} \mathrm{p}<0.05,{ }^{* * *} \mathrm{p}<0.01$. Region- and wave-clustered standard errors in parentheses. 


\begin{tabular}{|c|c|c|c|c|}
\hline & (1) & (2) & (3) & (4) \\
\hline & $\begin{array}{l}\text { Distances, with } \\
\text { predetermined } \\
\text { controls }\end{array}$ & $\begin{array}{l}\text { Distances, with full } \\
\text { controls }\end{array}$ & $\begin{array}{l}\text { Distances in either } \\
\text { direction, with } \\
\text { predetermined } \\
\text { controls }\end{array}$ & $\begin{array}{l}\text { Distances in either } \\
\text { direction, with full } \\
\text { controls }\end{array}$ \\
\hline Dest. $=\mathrm{II}$ & $-0.190^{* * *}(0.041)$ & $-0.087^{* *}(0.040)$ & $-0.184^{* * *}(0.041)$ & $-0.082^{* *}(0.040)$ \\
\hline Dest. $=$ III & $-0.331^{* * *}(0.060)$ & $-0.146^{* *}(0.060)$ & $-0.325^{* * *}(0.060)$ & $-0.141^{* *}(0.060)$ \\
\hline Dest. $=\mathrm{IV}$ & $-0.648^{* * *}(0.077)$ & $-0.403^{* * *}(0.076)$ & $-0.645^{* * *}(0.080)$ & $-0.402^{* * *}(0.080)$ \\
\hline Dest. $=\mathrm{V}$ & $-0.798^{* * *}(0.106)$ & $-0.508^{* * *}(0.103)$ & $-0.802^{* * *}(0.115)$ & $-0.516^{* * *}(0.113)$ \\
\hline Dest. $=\mathrm{VI}$ & $-0.928^{* * *}(0.121)$ & $-0.573^{* * *}(0.120)$ & $-0.942^{* * *}(0.136)$ & $-0.590^{* * *}(0.135)$ \\
\hline Dest. $=\mathrm{VII}$ & $-1.149^{* * *}(0.141)$ & $-0.747^{* * *}(0.134)$ & $-1.167^{* * *}(0.152)$ & $-0.768^{* * *}(0.147)$ \\
\hline Orig. $=\mathrm{II}$ & $0.008(0.040)$ & $0.018(0.040)$ & $0.013(0.040)$ & $0.023(0.040)$ \\
\hline Orig. $=$ III & $-0.033(0.058)$ & $-0.017(0.053)$ & $-0.017(0.058)$ & $-0.001(0.054)$ \\
\hline Orig. $=\mathrm{IV}$ & $0.000(0.062)$ & $-0.012(0.061)$ & $0.035(0.065)$ & $0.022(0.064)$ \\
\hline Orig. $=\mathrm{V}$ & $0.021(0.078)$ & $0.038(0.073)$ & $0.048(0.080)$ & $0.064(0.075)$ \\
\hline Orig. $=\mathrm{VI}$ & $0.071(0.080)$ & $0.083(0.078)$ & $0.090(0.082)$ & $0.101(0.080)$ \\
\hline Orig. $=\mathrm{VII}$ & $-0.002(0.085)$ & $0.012(0.082)$ & $0.012(0.086)$ & $0.026(0.083)$ \\
\hline Ref. class position & $-0.055^{*}(0.033)$ & $-0.022(0.033)$ & & \\
\hline Ref. class mobility & $-0.052^{+}(0.033)$ & $-0.081^{* * *}(0.031)$ & & \\
\hline Ref. class position (resp. is worse) & & & $-0.048^{+}(0.034)$ & $-0.014(0.033)$ \\
\hline Ref. class position (resp. is better) & & & $-0.051^{+}(0.033)$ & $-0.018(0.033)$ \\
\hline Ref. class mobility (resp. is worse) & & & $-0.023(0.033)$ & $-0.053^{*}(0.031)$ \\
\hline Ref. class mobility (resp. is better) & & & $-0.080^{* *}(0.036)$ & $-0.109^{* * *}(0.035)$ \\
\hline Fixed effects & YES & YES & YES & YES \\
\hline Predet. demogr. & YES & YES & YES & YES \\
\hline Education & $\mathrm{NO}$ & YES & $\mathrm{NO}$ & YES \\
\hline More demogr. & $\mathrm{NO}$ & YES & $\mathrm{NO}$ & YES \\
\hline UE \& income & $\mathrm{NO}$ & YES & $\mathrm{NO}$ & YES \\
\hline Log likelihood & -117043 & -115018 & -117033 & -115007 \\
\hline AIC & 234281 & 230255 & 234264 & 230237 \\
\hline $\mathrm{N}$ & 54990 & 54990 & 54990 & 54990 \\
\hline
\end{tabular}

$+\mathrm{p}<0.20,{ }^{*} \mathrm{p}<0.10,{ }^{* *} \mathrm{p}<0.05,{ }^{* * *} \mathrm{p}<0.01$. Region- and wave-clustered standard errors in parentheses. 
Table A6 Own class mobility effects in Eastern Europe, weights conditional on class destination

(1) with predetermined controls
Distance travelled
(2)

Distance travelled with full controls
(3)

Distance travelled up and down with predetermined controls

\begin{tabular}{|c|c|c|c|c|}
\hline Class $=I$ & $0.807^{* * *}(0.071)$ & $0.459^{* * *}(0.085)$ & $0.832^{* * *}(0.097)$ & $0.466^{* * *}(0.099)$ \\
\hline Class $=\mathrm{II}$ & $0.316^{* * *}(0.073)$ & $0.136^{* *}(0.068)$ & $0.309^{* * *}(0.083)$ & $0.133^{*}(0.072)$ \\
\hline Class $=\mathrm{III}$ & $0.050(0.096)$ & $-0.012(0.113)$ & $0.038(0.081)$ & $-0.017(0.098)$ \\
\hline Class $=I V$ & $-0.055(0.088)$ & $-0.047(0.089)$ & $-0.066(0.086)$ & $-0.048(0.091)$ \\
\hline Class $=\mathrm{V}$ & $-0.242^{+}(0.147)$ & $-0.132(0.211)$ & $-0.250^{*}(0.134)$ & $-0.129(0.200)$ \\
\hline Class $=\mathrm{VI}$ & $-0.498^{* * *}(0.044)$ & $-0.319^{* * *}(0.049)$ & $-0.483^{* * *}(0.046)$ & $-0.317^{* * *}(0.045)$ \\
\hline Class $=$ VII & $-0.378^{* * *}(0.112)$ & $-0.085(0.105)$ & $-0.381^{* * *}(0.100)$ & $-0.088(0.102)$ \\
\hline pI & $0.462^{* * *}(0.164)$ & $0.333(0.341)$ & $0.430^{* * *}(0.160)$ & $0.305(0.312)$ \\
\hline pII & $0.655^{* * *}(0.170)$ & $0.569(0.272)$ & $0.634^{* * *}(0.173)$ & $0.537^{* *}(0.272)$ \\
\hline pIII & $0.984^{* * *}(0.245)$ & $1.000(0.341)$ & $0.990^{* * *}(0.233)$ & $1.000(0.312)$ \\
\hline pIV & $0.763^{* * *}(0.145)$ & $0.783(0.386)$ & $0.818^{* * *}(0.203)$ & $0.798^{* *}(0.348)$ \\
\hline pv & $0.660^{* * *}(0.202)$ & $0.416(0.512)$ & $0.758^{* * *}(0.211)$ & $0.457(0.413)$ \\
\hline pVI & $0.725^{* * *}(0.205)$ & $0.503(0.375)$ & $0.845^{* * *}(0.300)$ & $0.632^{*}(0.356)$ \\
\hline pVII & $0.531^{* * *}(0.176)$ & $0.276(0.336)$ & $0.688^{*}(0.397)$ & $0.331(0.537)$ \\
\hline \#Classes moved & $0.054^{* *}(0.022)$ & $0.049^{* * *}(0.016)$ & & \\
\hline \#Classes up & & & $0.066^{*}(0.040)$ & $0.056^{* *}(0.028)$ \\
\hline \#Classes down & & & $-0.023(0.055)$ & $-0.042+(0.033)$ \\
\hline Fixed effects & YES & YES & YES & YES \\
\hline Predet. demogr. & YES & YES & YES & YES \\
\hline Education & $\mathrm{NO}$ & YES & $\mathrm{NO}$ & YES \\
\hline More demogr. & $\mathrm{NO}$ & YES & $\mathrm{NO}$ & YES \\
\hline UE \& income & $\mathrm{NO}$ & YES & $\mathrm{NO}$ & YES \\
\hline Log likelihood & -72664 & -71941 & -72663 & -71941 \\
\hline AIC & 145423 & 143999 & 145423 & 144001 \\
\hline $\mathrm{N}$ & 26620 & 26620 & 26620 & 26620 \\
\hline
\end{tabular}

(4)

Distance travelled up and down with full controls 
Table A7 Own class mobility effects in Eastern Europe, weights conditional on class origin

\begin{tabular}{|c|c|c|c|c|}
\hline & (1) & (2) & (3) & (4) \\
\hline & $\begin{array}{l}\text { Distance travelled } \\
\text { with predetermined } \\
\text { controls }\end{array}$ & $\begin{array}{l}\text { Distance travelled } \\
\text { with full controls }\end{array}$ & $\begin{array}{l}\text { Distance travelled } \\
\text { up and down with } \\
\text { predetermined } \\
\text { controls }\end{array}$ & $\begin{array}{l}\text { Distance travelled } \\
\text { up and down with } \\
\text { full controls }\end{array}$ \\
\hline Class $=\mathrm{I}$ & $0.754^{* * *}(0.103)$ & $0.531^{* * *}(0.101)$ & $0.860^{* * *}(0.109)$ & $0.550^{* * *}(0.107)$ \\
\hline Class $=\mathrm{II}$ & $0.308^{* * *}(0.097)$ & $0.144^{*}(0.085)$ & $0.325^{* * *}(0.105)$ & $0.137^{+}(0.100)$ \\
\hline Class $=$ III & $0.022(0.241)$ & $-0.355^{+}(0.223)$ & $-0.198(0.265)$ & $-0.304^{+}(0.214)$ \\
\hline Class $=I V$ & $-0.041(0.126)$ & $-0.064(0.192)$ & $-0.057(0.199)$ & $-0.051(0.168)$ \\
\hline Class $=\mathrm{V}$ & $-0.252^{+}(0.185)$ & $-0.100(0.184)$ & $-0.236(0.191)$ & $-0.110(0.158)$ \\
\hline Class $=\mathrm{VI}$ & $-0.481^{* * *}(0.078)$ & $-0.147^{* * *}(0.048)$ & $-0.360^{* * *}(0.075)$ & $-0.175^{* * *}(0.043)$ \\
\hline Class $=\mathrm{VII}$ & $-0.311^{* * *}(0.105)$ & $-0.010(0.076)$ & $-0.332^{* * *}(0.084)$ & $-0.047(0.072)$ \\
\hline pI & $0.588^{* * *}(0.129)$ & $0.486^{* * *}(0.137)$ & $0.613^{* * *}(0.156)$ & $0.614^{* * *}(0.141)$ \\
\hline PII & $0.520^{* * *}(0.111)$ & $0.455^{* *}(0.255)$ & $0.511^{* * *}(0.167)$ & $0.564^{* *}(0.289)$ \\
\hline pIII & $0.755^{* * *}(0.235)$ & $0.833^{* * *}(0.310)$ & $0.690^{* * *}(0.246)$ & $0.765^{* *}(0.307)$ \\
\hline piv & $0.932^{* * *}(0.241)$ & 1.000 (constr.) & $0.726^{* *}(0.332)$ & 1.000 (constr.) \\
\hline $\mathrm{pv}$ & $0.579^{* *}(0.272)$ & $0.479(0.518)$ & $0.269(0.241)$ & $0.356(0.408)$ \\
\hline pVI & $0.555^{* *}(0.241)$ & 0.000 (constr.) & $0.093(0.175)$ & 0.000 (constr.) \\
\hline PVII & $0.450^{+}(0.282)$ & 0.000 (constr.) & 0.000 (constr.) & 0.000 (constr.) \\
\hline \#Classes moved & $0.066^{*}(0.034)$ & $0.056^{* * *}(0.016)$ & & \\
\hline \#Classes up & & & $0.149^{* * *}(0.032)$ & $0.081^{* * *}(0.026)$ \\
\hline \#Classes down & & & $-0.049(0.045)$ & $-0.025(0.028)$ \\
\hline Fixed effects & YES & YES & YES & YES \\
\hline Predet. demogr. & YES & YES & YES & YES \\
\hline Education & $\mathrm{NO}$ & YES & $\mathrm{NO}$ & YES \\
\hline More demogr. & $\mathrm{NO}$ & YES & $\mathrm{NO}$ & YES \\
\hline UE \& income & $\mathrm{NO}$ & YES & $\mathrm{NO}$ & YES \\
\hline Log likelihood & -72672 & -71939 & -72665 & -71933 \\
\hline AIC & 145440 & 143990 & 145424 & 143983 \\
\hline $\mathrm{N}$ & 26620 & 26620 & 26620 & 26620 \\
\hline
\end{tabular}


Table A8 Reference class effects in Eastern Europe, weights conditional on class destination

\begin{tabular}{|c|c|c|c|c|}
\hline & (1) & (2) & (3) & (4) \\
\hline & $\begin{array}{l}\text { Distances, with } \\
\text { predetermined } \\
\text { controls }\end{array}$ & $\begin{array}{l}\text { Distances, with full } \\
\text { controls }\end{array}$ & $\begin{array}{l}\text { Distances in either } \\
\text { direction, with } \\
\text { predetermined } \\
\text { controls }\end{array}$ & $\begin{array}{l}\text { Distances in either } \\
\text { direction, with full } \\
\text { controls }\end{array}$ \\
\hline Class $=\mathrm{I}$ & $1.043^{* * *}(0.131)$ & $0.738^{* * *}(0.122)$ & $1.117^{* * *}(0.153)$ & $0.422^{* * *}(0.106)$ \\
\hline Class $=\mathrm{II}$ & $0.490^{* * *}(0.092)$ & $0.314^{* * *}(0.069)$ & $0.516^{* * *}(0.141)$ & $0.093(0.133)$ \\
\hline Class $=\mathrm{III}$ & $0.153^{*}(0.090)$ & $0.070(0.116)$ & $0.156^{* * *}(0.060)$ & $-0.054(0.087)$ \\
\hline Class $=\mathrm{IV}$ & $-0.056(0.081)$ & $-0.045(0.100)$ & $-0.079(0.076)$ & $0.235^{* *}(0.111)$ \\
\hline Class $=\mathrm{V}$ & $-0.317^{* *}(0.148)$ & $-0.208(0.177)$ & $-0.348^{* *}(0.137)$ & $-0.277(0.275)$ \\
\hline Class $=\mathrm{VI}$ & $-0.660^{* * *}(0.082)$ & $-0.492^{* * *}(0.072)$ & $-0.677^{* * *}(0.122)$ & $-0.256^{* *}(0.115)$ \\
\hline Class $=\mathrm{VII}$ & $-0.653^{* * *}(0.169)$ & $-0.376^{* * *}(0.136)$ & $-0.684^{* * *}(0.193)$ & $-0.163(0.222)$ \\
\hline pI & $0.455^{* * *}(0.140)$ & $0.317^{+}(0.211)$ & $0.453^{* * *}(0.117)$ & $0.255(0.409)$ \\
\hline PII & $0.610^{* * *}(0.126)$ & $0.491^{* * *}(0.177)$ & $0.626^{* * *}(0.124)$ & $0.452(0.385)$ \\
\hline PIII & $0.866^{* * *}(0.164)$ & $0.856^{* * *}(0.251)$ & $0.908^{* * *}(0.153)$ & 1.000 (constr.) \\
\hline pIV & $\left.0.706^{* * *} 0.105\right)$ & $0.653^{* * *}(0.170)$ & $0.831^{* * *}(0.151)$ & 0.000 (constr.) \\
\hline pv & $0.617^{* * *}(0.139)$ & $0.450^{*}(0.261)$ & $0.782^{* * *}(0.158)$ & $0.314(0.727)$ \\
\hline pvi & $0.647^{* * *}(0.155)$ & $0.502^{* *}(0.231)$ & $0.831^{* * *}(0.241)$ & 1.000 (constr.) \\
\hline pVII & $0.521^{* * *}(0.136)$ & $0.337^{+}(0.236)$ & $0.756^{* *}(0.307)$ & $0.607(0.475)$ \\
\hline \#Classes moved & $0.117^{* * *}(0.031)$ & $0.101^{* * *}(0.030)$ & & \\
\hline Ref. class position & $-0.064^{+}(0.041)$ & $0.011(0.042)$ & & \\
\hline Ref. class mobility & $-0.156^{* * *}(0.036)$ & $-0.132^{* * *}(0.032)$ & & \\
\hline \#Classes moved up & & & $0.121^{* * *}(0.033)$ & $0.082^{+}(0.052)$ \\
\hline \#Classes moved down & & & $-0.061(0.072)$ & $-0.043^{*}(0.025)$ \\
\hline Ref. class position (resp. is worse) & & & $-0.054(0.049)$ & $-0.052(0.058)$ \\
\hline Ref. class position (resp. is better) & & & $-0.065^{+}(0.040)$ & $-0.018(0.043)$ \\
\hline Ref. class mobility (resp. is worse) & & & $-0.172^{* * *}(0.038)$ & $-0.073^{* *}(0.035)$ \\
\hline Ref. class mobility (resp. is better) & & & $-0.149^{* * *}(0.043)$ & $-0.084^{+}(0.055)$ \\
\hline Fixed effects & YES & YES & YES & YES \\
\hline Predet. demogr. & YES & YES & YES & YES \\
\hline Education & $\mathrm{NO}$ & YES & $\mathrm{NO}$ & YES \\
\hline More demogr. & $\mathrm{NO}$ & YES & $\mathrm{NO}$ & YES \\
\hline UE \& income & $\mathrm{NO}$ & YES & $\mathrm{NO}$ & YES \\
\hline Log likelihood & -72616 & -71898 & -72614 & -71909 \\
\hline AIC & 145330 & 143923 & 145332 & 143940 \\
\hline $\mathrm{N}$ & 26607 & 26607 & 26607 & 26607 \\
\hline
\end{tabular}

$+\mathrm{p}<0.20,{ }^{*} \mathrm{p}<0.10,{ }^{* *} \mathrm{p}<0.05,{ }^{* * *} \mathrm{p}<0.01$. Region- and wave-clustered standard errors in parentheses. 
Table A9 Reference class effects in Eastern Europe, weights conditional on class origin

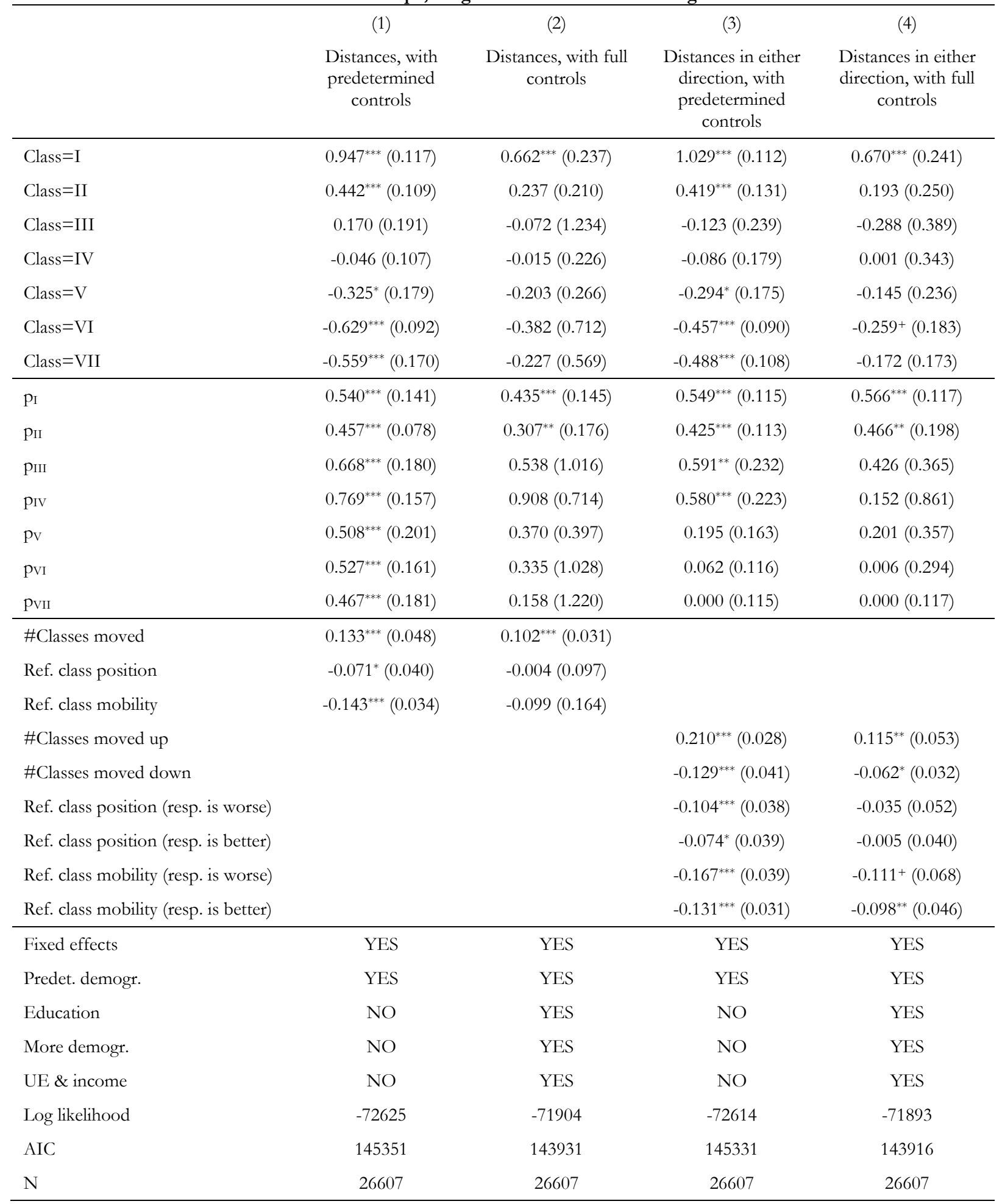

$+\mathrm{p}<0.20,{ }^{*} \mathrm{p}<0.10,{ }^{* *} \mathrm{p}<0.05,{ }^{* * *} \mathrm{p}<0.01$. Region- and wave-clustered standard errors in parentheses. 


\begin{tabular}{|c|c|c|c|c|}
\hline & (1) & (2) & (3) & (4) \\
\hline & $\begin{array}{l}\text { Distances, with } \\
\text { predetermined } \\
\text { controls }\end{array}$ & $\begin{array}{l}\text { Distances, with full } \\
\text { controls }\end{array}$ & $\begin{array}{l}\text { Distances in either } \\
\text { direction, with } \\
\text { predetermined } \\
\text { controls }\end{array}$ & $\begin{array}{l}\text { Distances in either } \\
\text { direction, with full } \\
\text { controls }\end{array}$ \\
\hline Dest. $=\mathrm{II}$ & $-0.352^{* * *}(0.051)$ & $-0.254^{* * *}(0.071)$ & $-0.357^{* * *}(0.054)$ & $-0.258^{* * *}(0.075)$ \\
\hline Dest. $=\mathrm{IV}$ & $-0.920^{* * *}(0.095)$ & $-0.631^{* * *}(0.107)$ & $-0.904^{* * *}(0.106)$ & $-0.612^{* * *}(0.115)$ \\
\hline Dest. $=\mathrm{V}$ & $-1.168^{* * *}(0.141)$ & $-0.743^{* * *}(0.173)$ & $-1.127^{* * *}(0.166)$ & $-0.696^{* * *}(0.181)$ \\
\hline Dest. $=\mathrm{VI}$ & $-1.498^{* * *}(0.124)$ & $-0.990^{* * *}(0.117)$ & $-1.433^{* * *}(0.178)$ & $-0.915^{* * *}(0.145)$ \\
\hline Orig. $=\mathrm{III}$ & $-0.180^{+}(0.137)$ & $-0.183^{+}(0.128)$ & $-0.184^{+}(0.135)$ & $-0.188^{+}(0.126)$ \\
\hline Orig. $=\mathrm{IV}$ & $-0.082(0.171)$ & $-0.086(0.159)$ & $-0.089(0.181)$ & $-0.093(0.168)$ \\
\hline Orig. $=\mathrm{V}$ & $-0.109(0.108)$ & $-0.141+(0.107)$ & $-0.113(0.109)$ & $-0.146+(0.106)$ \\
\hline Orig. $=\mathrm{VI}$ & $-0.081(0.094)$ & $-0.127^{+}(0.086)$ & $-0.080(0.093)$ & $-0.125^{+}(0.085)$ \\
\hline Orig.=VII & $0.031(0.103)$ & $0.035(0.091)$ & $0.033(0.102)$ & $0.037(0.091)$ \\
\hline Ref. position (distance) & $-0.068^{*}(0.040)$ & $0.004(0.039)$ & & \\
\hline Ref. mobility (distance) & $-0.146^{* * *}(0.039)$ & $-0.119^{* * *}(0.035)$ & & \\
\hline Fixed effects & YES & YES & YES & YES \\
\hline Predet. demogr. & YES & YES & YES & YES \\
\hline Education & $\mathrm{NO}$ & YES & $\mathrm{NO}$ & YES \\
\hline More demogr. & $\mathrm{NO}$ & YES & $\mathrm{NO}$ & YES \\
\hline UE \& income & $\mathrm{NO}$ & YES & $\mathrm{NO}$ & YES \\
\hline Log likelihood & -60600 & -60001 & -60599 & -60000 \\
\hline AIC & 121293 & 120119 & 121295 & 120120 \\
\hline $\mathrm{N}$ & 26607 & 26607 & 26607 & 26607 \\
\hline
\end{tabular}

$+\mathrm{p}<0.20,{ }^{*} \mathrm{p}<0.10,{ }^{* *} \mathrm{p}<0.05,{ }^{* * *} \mathrm{p}<0.01$. Region- and wave-clustered standard errors in parentheses. 